\title{
A Discussion on the Unique Features of Electrochemical Promotion of Catalysis (EPOC): Are We in the Right Path Towards Commercial Implementation?
}

\author{
Angel Caravaca *, Jesús González-Cobos and Philippe Vernoux *i1 \\ Institut de Recherches sur la Catalyse et l'Environnement de Lyon, UMR 5256, CNRS, Université Claude Bernard \\ Lyon 1, 2 Avenue A. Einstein, 69626 Villeurbanne, France; jesus.gonzalez-cobos@ircelyon.univ-lyon1.fr \\ * Correspondence: angel.caravaca@ircelyon.univ-lyon1.fr (A.C.); philippe.vernoux@ircelyon.univ-lyon1.fr (P.V.)
}

Received: 7 September 2020; Accepted: 24 October 2020; Published: 3 November 2020

\begin{abstract}
The phenomenon of "Non-Faradaic Electrochemical Modification of Catalytic Activity (NEMCA)" or "Electrochemical Promotion of Catalysis (EPOC)" has been extensively studied for the last decades. Its main strength, with respect to conventionally promoted catalytic systems, is its capability to modify in-situ the activity and/or selectivity of a catalyst by controlling the supply and removal of promoters upon electrical polarization. Previous reviews have summarized the main achievements in this field from both the scientific and technological points of view. However, to this date no commercial application of the EPOC phenomenon has been developed, although numerous advances have been made on the application of EPOC on catalyst nanostructures (closer to those employed in conventional catalytic systems), and on the development of scaled-up reactors suitable for EPOC application. The main bottleneck for EPOC commercialization is likely the choice of the right chemical process. Therefore, from our point of view, future efforts should focus on coupling the latest EPOC advances with the chemical processes where the EPOC phenomenon offers a competitive advantage, either from an environmental, a practical or an economic point of view. In this article, we discuss some of the most promising cases published to date and suggest future improvement strategies. The considered processes are: (i) ethylene epoxidation with environmentally friendly promoters, (ii) $\mathrm{NO}_{x}$ storage and reduction under constant reaction atmosphere, (iii) $\mathrm{CH}_{4}$ steam reforming with in-situ catalyst regeneration, (iv) $\mathrm{H}_{2}$ production, storage and release under fixed temperature and pressure, and (v) EPOC-enhanced electrolysers.
\end{abstract}

Keywords: electrochemical promotion of catalysis (EPOC); non-Faradaic electrochemical modification of catalytic activity (NEMCA); ionic conductor materials; ionic promoters

\section{Contents}

1. Introduction

1.1. EPOC: Opportunities for Catalytic Processes

1.2. Bridging the Gap to Practical Application of EPOC

1.2.1. Promotion of Metal/Metal Oxide Nanoparticles

1.2.2. Scale-Up EPOC Reactors

1.2.3. Suggested Catalytic and Electro-Catalytic Processes Suitable for EPOC 
2. The Case of Ethylene Epoxidation

2.1. Industrial Catalysts for Ethylene Epoxidation: Issues and Challenges

2.2. Discussion on EPOC Studies on Ethylene Epoxidation with $\mathrm{O}^{2-}$ Promoters

3. The Case of $\mathrm{NO}_{\mathrm{x}}$ Storage and Reduction (NSR)

3.1. Industrial Catalysts for NSR: Issues and Challenges

3.2. Discussion on Dynamic EPOC Studies on NSR with Alkaline Promoters

4. The Case of $\mathrm{H}_{2}$ Production by Catalytic Reforming

4.1. Industrial Catalysts for $\mathrm{CH}_{4}$ Steam Reforming: Issues and Challenges

4.2. Discussion on Dynamic EPOC Studies on Catalytic Steam Reforming with Alkaline Promoters

5. Coupling Electrolysis and EPOC

5.1. EPOC in Solid Oxide Electrolysers

5.2. EPOC in Depolarized PEM Electrolysers

\section{Introduction}

\subsection{EPOC: Opportunities for Catalytic Processes}

Nowadays it is well-known that electronic promoters are of paramount importance in heterogeneous catalysis, and some of the most popular industrial catalytic processes (e.g., ammonia synthesis [1], Fischer-Tropsch [2] and ethylene oxide synthesis [3]) use promoted catalysts to enhance their activity or their selectivity. In such catalysts, the promoter species are either added to the catalyst formulation during the synthesis process (this is usually the case for cationic promoters, such as $\mathrm{K}^{+}, \mathrm{Na}^{+}$or $\mathrm{Cs}^{+}[1,2]$ ), or together with the reactants in the reaction atmosphere (this is the case, for example, of chlorine electronegative promoters [3]). In general terms, these promoters modify the electronic properties of the catalyst active phase (usually a metal or metal oxide) and consequently the chemisorption (or desorption) of reactants (or products). All in all, under optimized reaction conditions, the use of electronic promoters leads to the activation of the catalyst towards higher activities and/or selectivities.

In the early 80s, the Vayenas team reported a breakthrough study using high temperature electrochemical cells for catalytic purposes [4]. More specifically, a $\mathrm{Ag}_{\text {film }} / \mathrm{YSZ}_{\text {disk }}$ electrochemical catalyst (catalyst-electrode/solid electrolyte) was used for the ethylene epoxidation reaction $\left(\mathrm{C}_{2} \mathrm{H}_{4}\right.$ $+0.5 \mathrm{O}_{2} \rightarrow \mathrm{C}_{2} \mathrm{H}_{4} \mathrm{O}$ ). The Ag film behaved as an active catalyst for the desired reaction, while yttriastabilized zirconia ( $\mathrm{YSZ}, \mathrm{Y}_{2} \mathrm{O}_{3}$-stabilized- $\mathrm{ZrO}_{2}, 8 \mathrm{~mol} \%$ ) was used as a solid electrolyte with the ability to move $\mathrm{O}^{2-}$ ions. This pioneering study discovered that the activity of the Ag catalyst could be drastically modified by imposing an electrical potential. Of course, an enhancement of the $\mathrm{C}_{2} \mathrm{H}_{4} \mathrm{O}$ production rate could be expected due to the contribution of the electrochemical oxidation of ethylene, since the $\mathrm{O}^{2-}$ ions migrate upon polarization, reaching the Ag catalyst and eventually reacting with ethylene $\left(\mathrm{C}_{2} \mathrm{H}_{4}+\mathrm{O}^{2-} \rightarrow \mathrm{C}_{2} \mathrm{H}_{4} \mathrm{O}+2 \mathrm{e}^{-}\right)$. However, it was found that the reaction rate enhancement was much higher than that predicted by the Faraday's law (which allows one to relate the flow of $\mathrm{O}^{2-}$ ions, $\mathrm{r}_{\mathrm{O} 2-}$, with the applied current, $\mathrm{I}: \mathrm{r}_{\mathrm{O} 2-}=\mathrm{I} / 2 \mathrm{~F}$ ). This enhancement was attributed to the role of $\mathrm{O}^{2-}$ ions as electronegative electronic promoters. That explains why a few years later this phenomenon was termed "Non-Faradaic Electrochemical Modification of Catalytic Activity (NEMCA)" [5] or "Electrochemical Promotion of Catalysis (EPOC)" [6]. The EPOC phenomenon has been widely studied by many research groups. To this date, some reviews have been published dealing with the main fundamental features of EPOC [7-12], the comparison of this phenomenon with conventional promotion of catalysis and metal support interactions (MSI) [13-17] and its potential 
practical implementation [7,18-20]. According to these studies, we can conclude that the EPOC phenomenon: (i) is not limited to any specific catalytic process, solid electrolyte material or catalyst active phase (metal or metal oxide), and (ii) is fundamentally similar but operationally different from the conventional promotion of catalysts usually applied for industrial processes. This last feature leads to one of the main advantages of the EPOC phenomenon: the promoter species can be in-situ supplied and removed upon electrical polarization. This underlines the EPOC potentiality to easily study the effect of certain types of promoters, i.e., alkaline promoters, on model catalysts with the aim to upgrade conventional catalytic formulations. Furthermore, with respect to conventional chemical promotion, the electrical consumption requirement of EPOC does not imply a significant handicap, as noticed from some simple estimations found in literature on the energy savings associated with EPOC [16]. However, herein we aim to address several unique and drastic benefits of EPOC which could make its industrial application competitive vs. conventional heterogeneous catalytic systems:

1. The activity/selectivity of a heterogeneous catalyst in a given reaction can be "in-operando" modified and optimized by tuning the applied potential/current. This process is potentially reversible since the applied polarization can be easily reversed, allowing for the removal of promoter species. These features could be significantly useful for dynamic chemical processes, such as activation/regeneration of catalysts, storage/desorption of species, etc. On the contrary, this is absolutely not possible when working with conventional promotion of catalysis, where the amount of promoter is fixed for a given catalytic process from the catalyst synthesis stage.

2. It allows to supply electro-negative $\mathrm{O}^{\delta-}$ promoter species, as previously described for the ethylene epoxidation reaction. This is not possible in conventional systems since $\mathrm{O}^{\delta-}$ cannot be formed via gaseous adsorption and cannot be easily dosed by chemical ways. These promoter species could potentially substitute highly toxic and hazardous electro-negative promoters commonly used in industrial catalysts (e.g., chlorine species).

3. The EPOC phenomenon could be used to enhance the performance of electro-catalytic processes (e.g., fuel cells and electrolysers) where the state-of-the-art electrochemical reactors (commercially available) are already featured with electrical connections. In view of the potential industrialization of EPOC, the currently available electro-catalytic reaction devices could be used straightforward for that purpose.

\subsection{Bridging the Gap to Practical Application of EPOC}

Regardless of these outstanding benefits of EPOC, to this date there is no real/commercial application of the EPOC phenomenon for industrial processes. In previous reviews by Tsiplakides and Balomenou [7,19,20] between 2005-2009, Anastasijevic [18] in 2009, and our group [12] in 2017, the following issues (among others) where identified as the bottlenecks for the industrial application of EPOC:

(a) "The use of less expensive catalysts and electrolyte systems needs to be put in focus of further development" [18].

(b) The importance of having the "ability to promote finely dispersed metal or metal oxide nanoparticles" [12].

(c) The need for "ease of electrical connection" and "efficient and compact reactor design" [20].

(d) "To boost NEMCA commercial application it is necessary to focus appropriate research and development on right targets, right chemical processes" [18].

Section 1.2.1 summarizes recent studies focused on issues (a) and (b) (cheap materials and electropromoted nanoparticles) while Section 1.2.2 briefly addresses the development on efficient reactors (issue c). On the other hand, the right targets and chemical processes (issue d) have not been systematically considered in literature. This is the main purpose of this review. We suggest in Section 1.2.3 some catalytic and electrocatalytic processes that could be suitable for a potential EPOC 
commercial implementation. Four proposed suggested chemical processes are then fully detailed and discussed in the second part of the review.

\subsubsection{Promotion of Metal/Metal Oxide Nanoparticles}

The search for the promotion of metal nanoparticles, with special attention on non-Pt group metals (PGMs), has been identified as one of the most important issues. While in conventional catalysts the metallic (or metal oxide) nanoparticles are highly dispersed on porous supports (e.g., $\gamma-\mathrm{Al}_{2} \mathrm{O}_{3}, \mathrm{CeO}_{2}$, etc.), in most of EPOC studies a thin porous and electronically conducting electrode layer (thickness in the nm-to- $\mu \mathrm{m}$ scale) is deposited on a dense solid electrolyte support. This electrode-like configuration leads to poorly dispersed materials with low specific activity of the metal. Different approaches to overcome this issue were recently reviewed [12] and are summarized below.

$\checkmark$ Some studies proposed the possibility to disperse the metallic active phase on electronically conductor materials, including Pt nanoparticles supported on a Au electrode [21], Pt supported on carbon (Vulcan) electrodes [22], $\mathrm{Ni}$ and $\mathrm{Ru}$ supported on carbon nanofibers [23] and $\mathrm{Pt}$ or $\mathrm{Ni}$ nanoparticles dispersed on a diamond-like carbon matrix $[24,25]$. In these cases, the metallic nanoparticles were successfully electrochemically promoted for different catalytic reactions including $\mathrm{CO}_{2}$ hydrogenation, $\mathrm{CO}+\mathrm{C}_{3} \mathrm{H}_{6}$ oxidation, methanol steam reforming and partial oxidation, respectively.

$\checkmark$ It was also possible to disperse the metallic nanoparticles on mixed ionic-electronic $\left(\mathrm{O}^{2-}, \mathrm{e}^{-}\right)$ conductors, including Pt/LSCF-GDC ( $\mathrm{LSCF}=\mathrm{La}_{0.6} \mathrm{Sr}_{0.4} \mathrm{Co}_{0.2} \mathrm{Fe}_{0.8} \mathrm{O}_{3}$ ) where Pt was prepared by impregnation [26], $\mathrm{Pt} / \mathrm{LSM}-\mathrm{GDC}\left(\mathrm{LSM}=\left(\mathrm{La}_{0.8} \mathrm{Sr}_{0.2}\right)_{0.95} \mathrm{MnO}_{3-\delta}\right)$ where $\mathrm{Pt}$ was prepared by atomic layer deposition (ALD) [27], and the electrodes prepared by the polyol method developed by the Baranova group, like $\mathrm{Ru} / \mathrm{CeO}_{2}$ [28] and $\mathrm{Pd} / \mathrm{Co}_{3} \mathrm{O}_{4}$ [29]. These highly dispersed materials were supported on YSZ solid electrolytes and tested, under EPOC conditions, for propylene, propane, ethylene and methane oxidation, respectively.

$\checkmark$ Another strategy was to increase the active surface area of the electrodes by developing nanoporous catalyst films by physical vapour deposition (PVD) techniques performed in oblique angle. This technique was optimized by the González-Elipe group for the development of an electrode formed by $\mathrm{Cu}$ nanocolumns tested for EPOC-assisted methanol partial oxidation [30] and an analogous Ni nanoporous catalyst film used for EPOC-assisted $\mathrm{H}_{2}$ production and storage [31].

\subsubsection{Scale-Up EPOC Reactors}

Together with an advanced catalyst development, efficient EPOC reactors should be designed and developed to become commercially attractive and to substitute the conventional catalytic reactors (fixed bed, monolithic, fluidized bed, etc.). The main handicap is clearly the need for electrical connections. The most important scale-up EPOC reactor designs have been summarized in previous reviews $[7,12,19,20]$. We will highlight the following two configurations:

$\checkmark$ EPOC multi-pellet reactor design for $\mathrm{NH}_{3}$ synthesis: This reactor design by Yiokari et al. constituted one of the first attempts to scale-up the EPOC catalysts, and was used for the $\mathrm{NH}_{3}$ synthesis process on commercial Fe-based catalyst (BASF S6-10RED) deposited on $\mathrm{CaZr}_{0.9} \mathrm{In}_{0.1} \mathrm{O}_{3-\alpha}$, a proton conducting solid electrolyte [32]. One of the most interesting technical features of this reactor is the possibility to operate at high pressure ( 50 bar), with 24 cell-pellets electrically connected in parallel.

$\checkmark$ EPOC with monolithic electrochemically promoted reactors (MEPR): This reactor developed by the Vayenas group consists of up to 22 electrocatalytic plate cells $\left(5 \times 5 \mathrm{~cm}^{2}\right)$ in parallel exposed to the same reaction atmosphere [33]. The plate cells are composed of dense square solid electrolytes (e.g., YSZ) with a catalytic film deposited on each side. The reactor is equipped of two external connecting wires for polarization purposes. This reactor has been used, for instance, for the oxidation of ethylene [33,34] and $\mathrm{SO}_{2}[35]$ on Pt electrodes and reduction of $\mathrm{CO}_{2}$ on $\mathrm{Rh}$ and 
$\mathrm{Cu} / \mathrm{TiO}_{2}$ electrodes [36]. Also, a MEPR with $22 \mathrm{Rh} / \mathrm{YSZ} / \mathrm{Pt}$ plates was successfully tested under real conditions for the treatment of an automotive exhaust gas of a diesel engine $[37,38]$.

\subsubsection{Suggested Catalytic and Electro-Catalytic Processes Suitable for EPOC}

This is the issue where we aim to focus more and around which the entire article is organized. In spite of the important progress described above regarding materials and reactors development, we believe that one of the main reasons why the EPOC phenomenon has not yet been applied commercially is due to the need to find the right chemical processes. Even if EPOC is not limited to any chemical reaction, it is worth considering that the substitution of the conventional catalytic systems by electrochemically promoted devices requires a significant investment that must be completely justified. In our opinion, only in catalytic processes where EPOC is completely justified, and once the proper technological development is carried out in those cases, industry will consider implementing it. In this sense, from our point of view, future research efforts should focus on the chemical processes where EPOC can offer unique features, leading to significant environmental, practical or economic advantages.

For example, catalytic reactions like $\mathrm{CO}$ oxidation or $\mathrm{CO}_{2}$ hydrogenation, among many others, have been widely studied from the perspective of electrochemical promotion of catalysis $[15,16]$ but, from the practical point of view, EPOC barely shows any additional competitive advantage in these cases, vs. conventional chemical promotion, besides the "in-situ" character. Hence, this review is a discussion article about the actual research pathways to commercialize EPOC. The idea of this article is to highlight and discuss some EPOC studies that, from the authors point of view, deal with chemical processes in which the scale-up of EPOC at an industrial level could have an actual interest, after the proper technological development (Figure 1).

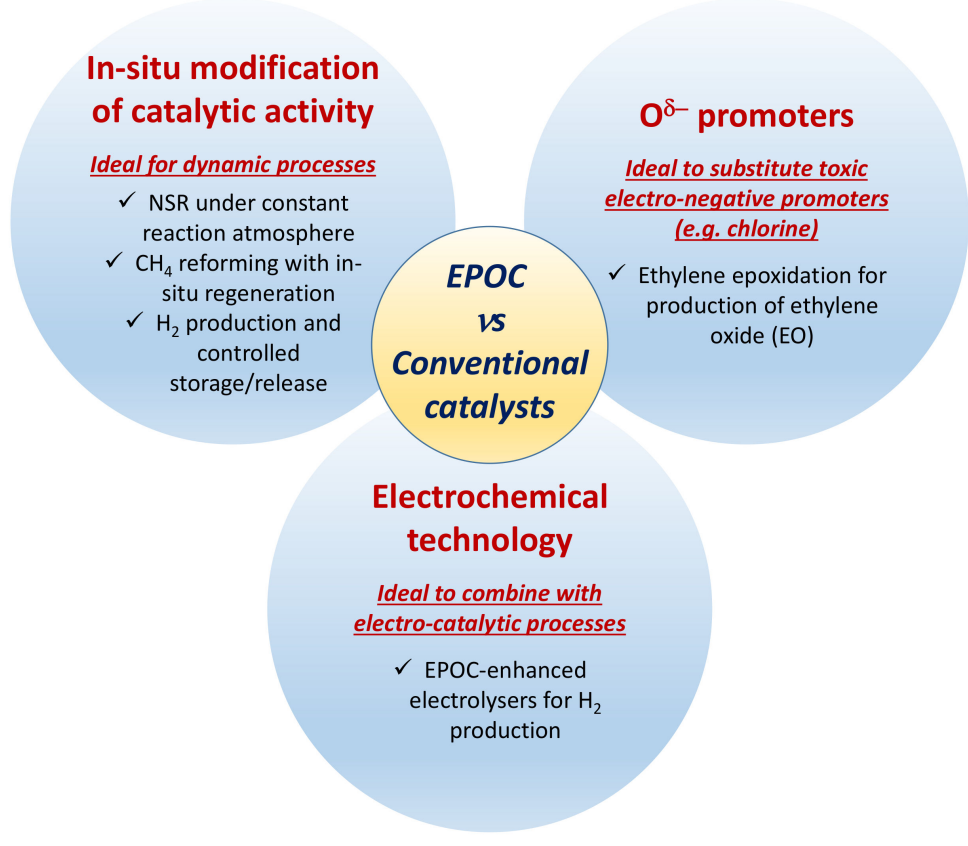

Figure 1. Suggested EPOC applications with unique benefits compared to conventional catalytic processes.

We have considered: (i) the ethylene epoxidation with $\mathrm{O}^{\delta-}$ promoters (instead of chlorine promoters typically used in conventional catalysts), (ii) the $\mathrm{NO}_{\mathrm{x}}$ storage and reduction (NSR) process under a constant reaction atmosphere (without the rich pulses required for the regeneration in current NSR technologies), (iii) The case of $\mathrm{H}_{2}$ production by catalytic reforming and iv) the EPOC-enhanced electrolysers (advanced technology to increase the $\mathrm{H}_{2}$ production efficiency of current electrolysers). The first three catalytic reactions are mature but EPOC can provide an environmentally friendly new route that could be imposed by regulations in a near future. EPOC could also decrease the operation 
costs by in-situ smoothing or optimizing operating conditions to save fuel $\left(\mathrm{NO}_{\mathrm{x}} \mathrm{TRAP}\right)$, expensive noble metals (NOx TRAP), improve the yield (epoxidation) and the durability (steam reforming). However, one of the main bottlenecks for the potential EPOC implementation would be the upgrade of the catalytic configurations and reactor designs. Therefore, the presumably high investment costs have to be counter-balanced with the gain in the operation costs.

On the other hand, we have also considered depolarized PEM electrolysers and solid oxide electrolysers. These two technologies under development could be combined with EPOC to increase their global efficiency. In addition, EPOC can be directly implemented in electrolysers without significant investment costs. The actual high intrinsic cost of green hydrogen produced by these electrolysers could be lowered by the coupling with EPOC.

\section{The Case of Ethylene Epoxidation}

\subsection{Industrial Catalysts for Ethylene Epoxidation: Issues and Challenges}

Ethylene epoxidation is the industrial chemical process that produces ethylene oxide (EO). EO is a chemical product used as disinfectant and sterilizing agent, and more importantly, it constitutes a chemical intermediate to produce a wide variety of added-value molecules, including plastics, polyester and ethylene glycol. That is why, with an annual production of 35 million tons, the production of EO is nowadays one of the major catalytic processes in the chemical industry. The ethylene epoxidation process is performed industrially in the presence of silver catalysts supported on $\alpha$-alumina $\left(\mathrm{Ag} / \alpha-\mathrm{Al}_{2} \mathrm{O}_{3}\right)[39,40]$ at intermediate temperatures $\left(<300{ }^{\circ} \mathrm{C}\right)$ and pressures $(10-30 \mathrm{bar})$. The choice of $\mathrm{Ag}$ is based on its ability to catalyze the selective addition of oxygen atoms from molecular $\mathrm{O}_{2 \text { gas }}$ across the $\mathrm{C}=\mathrm{C}$ bond in ethylene. That allows for the partial oxidation of ethylene towards $\mathrm{EO}\left(\mathrm{C}_{2} \mathrm{H}_{4}+\right.$ $\left.\frac{1}{2} \mathrm{O}_{2} \rightarrow \mathrm{C}_{2} \mathrm{H}_{4} \mathrm{O}\right)$, instead of the undesired total combustion process $\left(\mathrm{C}_{2} \mathrm{H}_{4}+3 \mathrm{O}_{2} \rightarrow 2 \mathrm{CO}_{2}+2 \mathrm{H}_{2} \mathrm{O}\right)$. Even though the reaction mechanism for this catalytic process is still under debate, it is believed that these active oxygen species exhibit an electrophilic nature and are therefore weakly adsorbed on the $\mathrm{Ag}$ active sites [41,42]. In the absence of promoters, the selectivity towards $\mathrm{EO}$ on $\mathrm{Ag} / \alpha-\mathrm{Al}_{2} \mathrm{O}_{3}$ catalysts is rarely higher than $50 \%$ [43]. In this sense, the addition of promoters like $\mathrm{Cs}$ and, specially, chlorine species (added for instance in the form of vinyl chloride or ethyl chloride) is required to increase the EO selectivity in a significant manner up to $80 \%[44,45]$ or even higher. For example, with only $8 \%$ at of $\mathrm{Cl}$ on the Ag surface, the EO selectivity can increase from 9 to nearly 60\% [46]. Many explanations for the behavior of $\mathrm{Cl}$ promoters in ethylene epoxidation have been proposed [3]. Nevertheless, it is generally accepted that $\mathrm{Cl}$ weakens the $\mathrm{Ag}-\mathrm{O}$ interaction [47], leading to the production of weakly adsorbed electrophilic oxygen species on the Ag active sites. Despite this increase of the EO selectivity, the use of this kind of promoters generally decreases the overall reaction yield by site blocking effect. In addition, it is well known that the chlorinated precursors are not environmentally friendly and are highly toxic for human health. For instance, vinyl chloride (primarily used in the production of polyvinyl chloride, PVC) is now classified as an International Agency for Research on Cancer (IARC) Group 1 carcinogen [48]. Therefore, the main challenge is to substitute the currently used chlorine species by environmentally friendly/non-toxic electro-negative promoters. In this sense, the EPOC phenomenon is of particular interest since, as previously mentioned in the introduction section, previous studies proved that it allows to enhance the $\mathrm{EO}$ selectivity using $\mathrm{O}^{\delta-}$ promoter species.

\subsection{Discussion on EPOC Studies on Ethylene Epoxidation with $\mathrm{O}^{2-}$ Promoters}

The first study of EPOC dealt with the ethylene epoxidation reaction on $\mathrm{Ag}_{\mathrm{EO}} / \mathrm{YSZ} / \mathrm{Ag}_{\text {air }}$ electrochemical cells at $400{ }^{\circ} \mathrm{C}$ and atmospheric pressure [4]. These cells were placed in double chamber solid oxide cell reactors (typically used for solid oxide fuel cells, SOFC), where one of the Ag electrodes $\left(\mathrm{Ag}_{\mathrm{air}}\right)$ was exposed to the air, and the other one $\left(\mathrm{Ag}_{\mathrm{EO}}\right)$ to an ethylene epoxidation reaction atmosphere, i.e., $\mathrm{C}_{2} \mathrm{H}_{4}+\mathrm{O}_{2}$. In this early study, it was already observed that upon the application of positive polarizations on the $\mathrm{Ag}_{\mathrm{EO}}$ electrode behaving as working electrode (i.e., $\mathrm{O}^{2-}$ ions pumping to 
the $\mathrm{Ag}_{\mathrm{EO}}$ electrode), both the selectivity and yield of $\mathrm{EO}$ increased, in contrast to conventional chemical promotion with $\mathrm{Cl}$ or $\mathrm{Cs}$ dopants $[44,45,47]$. The increase in the rate of $\mathrm{EO}$ production exceeded the rate of $\mathrm{O}^{2-}$ pumping by a factor of 400 . This was the first ever-reported proof that the electrochemically supplied oxygen species behave as electronic promoters for a catalytic process.

Aiming for a better understanding of this specific system, two studies were performed by in-situ surface enhanced Raman spectroscopy (SERS) upon polarization under ethylene epoxidation conditions $[49,50]$, where one of the main conclusions was that the molecular oxygen is not the catalytically active species, in good agreement with the EPOC fundamentals. However, the nature of the oxygen promoter (not specifically for this reaction) was later studied by a wide variety of techniques, as recently reviewed by our group [12], including $\mathrm{O}_{2}$-Temperature-programmed desorption (TPD), X-ray photoelectron spectroscopy (XPS), cyclic voltammetry, photoemission electron microscopy (PEEM), etc. All these techniques reached the common conclusion that the electrochemical supply of $\mathrm{O}^{2-}$ species to a catalyst surface produces more strongly adsorbed ionic and partially discharged $\mathrm{O}^{\delta-}$ oxygen species, causing either repulsive lateral interactions with electron acceptor species (e.g., co-adsorbed oxygen) or attractive ones with co-adsorbed electron donor adsorbates (e.g., hydrocarbons). This mechanism is called "sacrificial promoter" mechanism, where the term "sacrificial" implies that the promoting species originating from $\mathrm{O}^{2-}$ in the $\mathrm{YSZ}$ are also consumed on account of electrocatalytic processes, but at a rate slower than the electropromoted catalytic rate [13,15].

A more detailed EPOC study on ethylene epoxidation was performed a few years later in a similar double chamber electrochemical cell under a wider range of reaction conditions $\left(350-470{ }^{\circ} \mathrm{C}\right)$ [51]. In this case, the observed promotional phenomenon was attributed to the modification of the surface population of different types of adsorbed oxygen species upon polarization. In other words, the application of positive potentials led to the $\mathrm{O}^{2-}$ pumping from the YSZ solid electrolyte to the Ag catalyst, weakening the adsorption of oxygen and enhancing the population of electrophilic oxygen species, similarly to what is observed upon $\mathrm{Cl}$ promotion $[46,47]$. These species interact with the $\pi$ orbitals of adsorbed $\mathrm{C}_{2} \mathrm{H}_{4}$ (leading to the epoxidation reaction) instead of the undesired cleavage of $\mathrm{C}-\mathrm{H}$ bonds (leading to total combustion).

In two later studies, the ethylene epoxidation reaction was performed in a similar electrochemical system, but under reaction conditions closer to those used in the industrial process, i.e., low temperatures $\left(<300{ }^{\circ} \mathrm{C}\right)$, higher pressures $(5 \mathrm{bar})$ and even in the presence of chlorine promoters [52,53]. The promotional effect observed was in good agreement with the aforementioned studies. It was also found that the addition of chlorine caused qualitatively similar effects on the selectivity to ethylene oxide, and a constructive synergy exists upon the application of positive polarizations under the presence of chlorine promoters, as observed in Figure 2. In this figure one can observe that both ethylene oxide and $\mathrm{CO}_{2}$ production rates can be enhanced by increasing either the $\mathrm{Cl}$ doping or the applied potential in a certain range. For example, in the absence of $\mathrm{Cl}$ (where the obtained open circuit potential was $-197 \mathrm{mV}$ [53]), the application of a catalyst potential of $36 \mathrm{mV}$ multiplied the ethylene oxide production by more than three. A maximum selectivity towards ethylene oxide of c.a. $78 \%$ was reached under optimum conditions, by combining $0.3 \mathrm{ppm} \mathrm{C}_{2} \mathrm{H}_{4} \mathrm{Cl}_{2}$ and a catalyst potential of $-156 \mathrm{mV}$ [53].

All these studies have demonstrated that the EPOC phenomenon can enhance the catalytic activity of the ethylene epoxidation reaction towards the production of EO. The oxygen species behave as electronic "sacrificial promoters", meaning that for a certain period they will create the dipole needed to modify the chemisorptive properties of the Ag catalyst. This EPOC approach offers outstanding advantages compared to the traditional industrial catalytic systems. The effect of adding oxygen promoters $\left(\mathrm{O}^{\delta-}\right)$ to the Ag catalyst surface enhanced the activity and selectivity towards the production of EO. This effect seems to be functionally similar to that of chlorine species, and even better since oxygen promoters enhance the catalyst selectivity without decreasing the overall activity. Therefore, EPOC could potentially substitute the traditional promoters by environmentally friendly/non-toxic/non-hazardous species. This feature completely justifies the implementation of the 
EPOC technology for this specific process. Furthermore, the promoted activity can be in-situ optimized via applied polarization. However, the following issues should be considered to improve this EPOC approach in view of its practical implementation:

$\boldsymbol{V}$ The Ag catalysts used in all these EPOC studies were prepared by the thermal decomposition of organometallic paste precursors. This procedure results in a catalyst with a poor metallic dispersion compared to that of commercial materials. This implies that, to achieve similar reaction rates, a much higher amount of Ag should be used in the EPOC catalysts, which is not sustainable from an economic point of view.

$\boldsymbol{V}$ These studies were performed in reactors usually designed for electrochemical (rather than catalytic) purposes, e.g., solid oxide fuel cells.

$\checkmark$ Based on the premises of the "sacrificial promoter" mechanism, after a limited period of time, the $\mathrm{O}^{\delta-}$ promoter species may react with ethylene through a purely electro-catalytic process $\left(\mathrm{C}_{2} \mathrm{H}_{4}\right.$ $\left.+\mathrm{O}^{2-} \rightarrow \mathrm{C}_{2} \mathrm{H}_{4} \mathrm{O}+2 \mathrm{e}^{-}\right)$or evolve in form of molecular oxygen $\left(2 \mathrm{O}^{2-} \rightarrow \mathrm{O}_{2}+2 \mathrm{e}^{-}\right)$. Therefore, a continuous supply of promoting oxygen species is required via applied potential to maintain the promoted state of the catalyst. Hence, even though the required currents are generally rather small (of the order of a few $\mu \mathrm{A}-\mathrm{mA}$ ), constant or periodic electrical currents should be applied.

Recent advances in EPOC technologies could overcome the two first issues. Regarding the reactor design, since industrial ethylene epoxidation is usually performed at a pressure over the atmospheric conditions, we believe that the first EPOC reactor, already tested at high pressures for the $\mathrm{NH}_{3}$ synthesis process [32], could be easily adapted for the scale-up of such catalytic process.
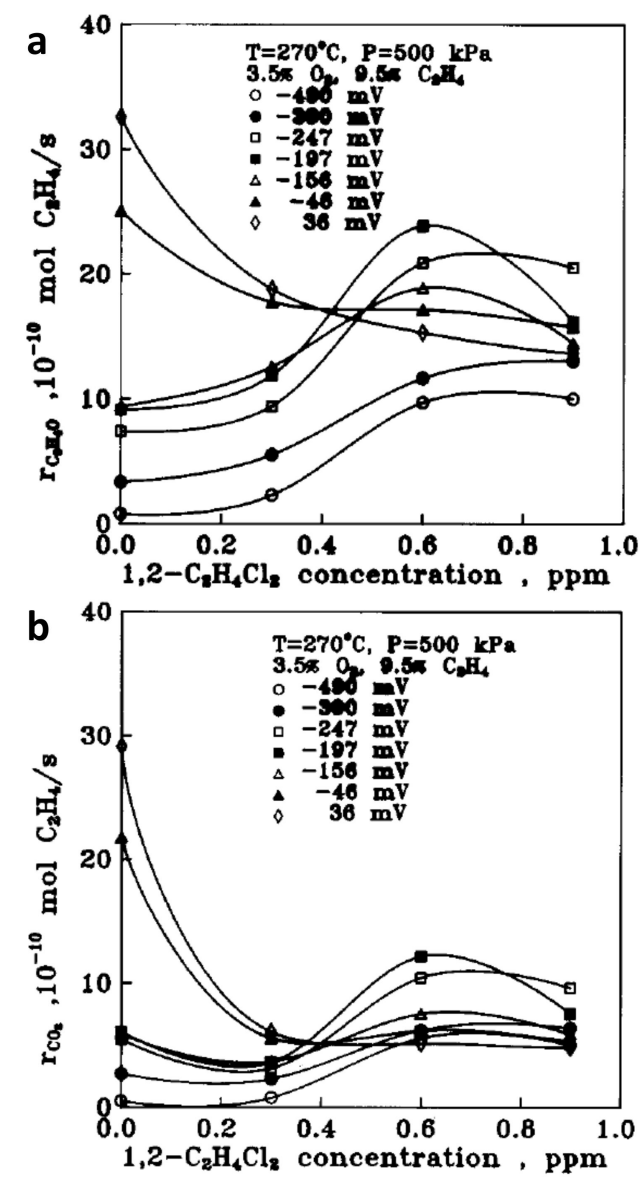

Figure 2. Ethylene oxide (a) and $\mathrm{CO}_{2}(\mathbf{b})$ production rates on an $\mathrm{Ag} / \mathrm{YSZ}$ electrochemical catalyst and tested for ethylene epoxidation reaction with different $\mathrm{C}_{2} \mathrm{H}_{4} \mathrm{Cl}_{2}$ gas phase concentrations and applied catalyst potentials $\left(\mathrm{V}_{\mathrm{WR}}\right)$. Reprinted with permission from [53]. 
In order to enhance the dispersion of silver on the Ag/YSZ electrochemical catalyst, Ag could be dispersed on a mixed ionic-electronic conductor similarly to other composites employed for EPOC [26-29]. In addition, a very attractive alternative solution could be to finely disperse Ag nanoparticles on a high specific surface to achieve an $\mathrm{O}^{\delta-}$ promoted state of the Ag catalyst without any polarization, on the basis of the metal support interactions (MSI). It is well established in the field of catalysis that some oxide supports, including gadolinium-doped ceria (GDC) and YSZ have an active role in the catalytic mechanism $[15,54-56]$. The Vayenas group was the first to establish an equivalence between MSI and EPOC, in a way that traditional EPOC can be considered as an electrochemically controlled MSI [57]. Put differently, MSI can be considered as a type of "self-sustained electrochemical promotion" (SSEP) [12,58-61] and also led to the so-called "wireless EPOC" in a double chamber reactor configuration $[62,63]$. This way, conventional catalytic reactors could be directly used for this MSI approach, as well as other kind of reactors based on perovskite-like hollow fiber membranes like the one developed by the Metcalfe group [64]. Besides, the Baranova team has made recent advances in the development of materials promoted by MSI by using the polyol method for the preparation of several metal and metal oxide nanoparticles with controlled particle size over different oxygen conducting supports (e.g., ceria, titania, YSZ). In the present case, since the ethylene epoxidation process is a steady-state technology, with catalysts employed under optimized steady reaction conditions, we argue that working with self-promoted Ag/YSZ composites (via MSI) could potentially substitute the current industrial technology which is using toxic chlorine promoters.

Table 1 summarizes the main features of the EPOC approach for the ethylene epoxidation. To decide which approach is the most convenient (conventional EPOC or MSI), the following question should be answered: is it strictly necessary to control the amount of $\mathrm{O}^{\delta-}$ species in-situ for promoting the ethylene epoxidation reaction? Of course, that would be the ideal situation. However, we believe that in this specific case, the MSI concept should be strongly encouraged. This way, the currently used catalytic reactors would not be drastically modified (as it would be the case to implement conventional EPOC technologies) and the whole operation for EO production would not be altered in a significant manner from a technological point of view.

Table 1. Main issues and benefits of the EPOC-assisted ethylene epoxidation.

\begin{tabular}{|c|c|}
\hline \multicolumn{2}{|c|}{ The Case of EPOC-Assisted Ethylene Epoxidation } \\
\hline \multirow{2}{*}{ Conventional catalysts } & Issues \\
\hline & Use of toxic chlorine promoters \\
\hline \multirow{7}{*}{ EPOC approach } & Benefits \\
\hline & Substitution of chlorine promoters by $\mathrm{O}^{\delta-}$ (non-toxic) \\
\hline & in-situ optimization of promoted state by applied polarization \\
\hline & Issues \\
\hline & Non-optimized Ag catalyst: low dispersion = low activity \\
\hline & $\mathrm{O}^{\delta-}$ sacrificial promoter: constant current application \\
\hline & Reactor design \\
\hline
\end{tabular}

\section{The Case of NOx Storage and Reduction (NSR)}

\subsection{Industrial Catalysts for NSR: Issues and Challenges}

The $\mathrm{NO}_{\mathrm{x}}$ storage and reduction (NSR) technology was developed in the mid-1990s by Toyota Laboratories [65-67]. The aim of this technology is to provide an efficient vehicles after-treatment system capable of reducing tailpipe nitrogen oxides $\left(\mathrm{NO}_{\mathrm{x}}=\mathrm{NO}+\mathrm{NO}_{2}\right)$ to levels below the legislation limits. This is mainly applied to internal combustion engines working under lean-burn conditions (i.e., air excess in the combustion chamber) such as Diesel engines. The most common NSR catalyst 
formulation studied in literature includes a noble metal $(\mathrm{Pt})$ for catalytic reactions, and a $\mathrm{NO}_{\mathrm{x}}$ sorbent/storage component $(\mathrm{BaO})$ supported on $\gamma-\mathrm{Al}_{2} \mathrm{O}_{3}$. Hence the model NSR catalyst is commonly designated as $\mathrm{Pt} / \mathrm{BaO} / \mathrm{Al}_{2} \mathrm{O}_{3}[68-70]$. These catalysts allow to reduce $\mathrm{NO}_{\mathrm{x}}$ emissions in a cyclic operation with periodic switches between lean (the engine exhaust) and rich conditions. $\mathrm{NO}$ (the major $\mathrm{NO}_{\mathrm{x}}$ species) contained in the exhaust is oxidized to $\mathrm{NO}_{2}$ on the Pt active sites $\left(\mathrm{NO}+\frac{1}{2} \mathrm{O}_{2} \rightarrow \mathrm{NO}_{2}\right)$. Then, the $\mathrm{NO}_{2}$ is trapped in form of nitrite/nitrate species. As far as the NSR catalyst surface is saturated, a fuel post-injection is triggered (rich pulses) to decompose nitrates owing to their low thermodynamic stability in this reducing environment and $\mathrm{NO}_{\mathrm{x}}$ released is reduced to $\mathrm{N}_{2}$ on precious metal (i.e., $\mathrm{Pt}$, Rh). The NSR technology is industrially applied on many Diesel light vehicles. However, short fuel injections (3-5 s) lead to a significant fuel penalty and therefore to an economic impact. A new EPOC approach has been proposed in the literature to remove the rich pulses and to operate the NSR process under constant lean-burn conditions.

\subsection{Discussion on Dynamic EPOC Studies on NSR with Alkaline Promoters}

The use of electrochemical catalysts for the reduction of $\mathrm{NO}_{\mathrm{x}}$ into hazardless $\mathrm{N}_{2}$ has been widely reported in literature. Some studies aimed for the direct electro-catalytic decomposition of $\mathrm{NO}_{\mathrm{x}}$ by using $\mathrm{O}^{2-}$ conductor solid electrolytes [71-73] in solid oxide fuel cell-type reactors. In that approach, upon the application of electrical polarizations, $\mathrm{NO}_{\mathrm{x}}$ are reduced on one electrode (i.e., $\mathrm{Pt}$ or $\mathrm{NiO}$ ) into $\mathrm{N}_{2}$ and $\mathrm{O}^{2-}$ ions $\left(\mathrm{NO}_{\mathrm{x}}+2 \mathrm{x} \mathrm{e}^{-} \rightarrow \frac{1}{2} \mathrm{~N}_{2}+\mathrm{xO}^{2-}\right)$. Unfortunately, $\mathrm{NO}_{x}$ electrochemical reduction to $\mathrm{N}_{2}$ is strongly hindered in the presence of $\mathrm{O}_{2}$, owing to the kinetically enhanced $\mathrm{O}_{2}$ electroreduction $v \mathrm{~s}$. NO. The presence of a $\mathrm{NO}_{\mathrm{x}}$ adsorption component (i.e., an alkali or alkaline earth metal oxide) can enhance this process through the formation of intermediate nitrate species [74-76]. This latter electrochemical approach is very close to the NSR process, and potentially could allow to perform the $\mathrm{NO}_{\mathrm{x}}$ reduction under a constant lean reaction atmosphere. This technology combines $\mathrm{NO}_{\mathrm{x}}$ adsorption processes with electro-catalytic decomposition reactions. However, its performance has not been claimed to be modified owing to the EPOC phenomenon even if the competitive chemisorption between $\mathrm{NO}$ and $\mathrm{O}_{2}$ could be potentially modified upon polarization. Some other studies aimed for the application of the EPOC phenomenon to the "selective catalytic reduction" of $\mathrm{NO}_{x}$ with some reducing gases present in the exhaust gas (e.g., $\mathrm{CO}$ and unburnt hydrocarbons). These technologies have been already reviewed in previous works $[77,78]$. For instance, fundamental EPOC studies with alkaline promoters have been carried out by Williams, Lambert and co-workers on $\mathrm{NO}$ reduction by $\mathrm{CO}$ or $\mathrm{C}_{3} \mathrm{H}_{6}$ [79-85].

In this section, we will highlight the studies dealing with the dynamic application of EPOC to the NSR technology in view of its potential practical implementation. Only two studies have been previously reported. The first work consisted of a fundamental proof-of-concept study by the use of a $\mathrm{Pt} / \mathrm{K}^{+}-\beta^{\prime \prime} \mathrm{Al}_{2} \mathrm{O}_{3}$ electrochemical catalyst [86] in a single chamber reactor configuration, where both electrodes where under the same reaction atmosphere. $\mathrm{Pt}$ film was prepared by the application and thermal decomposition of an organometallic paste, and $\mathrm{K}^{+}-\beta^{\prime \prime} \mathrm{Al}_{2} \mathrm{O}_{3}$ was used as solid electrolyte exhibiting $\mathrm{K}^{+}$ionic conductivity. These alkali ions provide the $\mathrm{NO}_{\mathrm{x}}$ storing sites, in a similar way to that of $\mathrm{BaO}$ commonly used in conventional NSR catalysts. However, as opposed to those, the $\mathrm{K}^{+}$ ions can be supplied backward and forward to the Pt catalyst upon polarization. The most interesting results of this study were obtained under constant ideal simulated lean conditions: $N O / \mathrm{C}_{3} \mathrm{H}_{6} / \mathrm{O}_{2}$ : $1100 \mathrm{ppm} / 1000 \mathrm{ppm} / 5 \%$, by step changes in the applied potential from positive to negative polarizations showing a very reproducible cyclic behavior (Figure 3).

Under the application of a negative potential $\left(-1.5 \mathrm{~V}\right.$, migration of $\mathrm{K}^{+}$cations towards $\mathrm{Pt}$ ), the measured outlet concentration of $\mathrm{NO}_{x}$ dynamically decreased to a minimum value, increasing later to the inlet concentration value. This stage was explained on the basis of the EPOC phenomenon with $\mathrm{K}^{+}$promoters which has been thoroughly studied and reported in literature for a wide variety of applications $[10,11,14]$. When negative polarizations are applied on the catalyst film behaving as working electrode, $\mathrm{K}^{+}$ions migrate from the solid electrolyte to the catalyst surface and, in a similar way to that previously explained for $\mathrm{O}^{2-}$ promoters, modify the electronic properties of 
the catalyst. The presence of $\mathrm{K}^{+}$ions decreases the Pt work function, enhancing the chemisorption of electron-acceptor species, favoring in this case $\mathrm{NO}$ and $\mathrm{O}_{2}$ chemisorption at the expense of the hydrocarbon. The $\mathrm{K}^{+}$ions electrochemically supplied behave in a similar way than conventional alkali promoters used in traditional catalysts, as we previously reviewed [14]. The oxidation of $\mathrm{NO}$ into $\mathrm{NO}_{2}$, which has been identified as the first step of the NSR process, is electropromoted. Once $\mathrm{NO}_{2}$ is formed, $\mathrm{K}^{+}$ions also behave as $\mathrm{NO}_{\mathrm{x}}$ trapping species, explaining why the outlet $\mathrm{NO}_{\mathrm{x}}$ outlet concentration decreased upon negative polarizations. Even if the storage step is purely chemical, EPOC is essential to enhance the oxidation of NO. Very interestingly, under the application of positive potentials $(+3 \mathrm{~V}$, still under lean conditions), for a few minutes, the outlet concentration of $\mathrm{NO}_{\mathrm{x}}$ was much lower than that expected from the release of $\mathrm{NO}_{\mathrm{x}}$ species previously stored. The mass-balance calculations clearly show that a part of $\mathrm{NO}_{x}$ has been electrochemically reduced into $\mathrm{N}_{2}$. This was explained by the impact of the positive polarization that can promote the chemisorption of the hydrocarbon (EPOC), enhancing the selective catalytic reduction of $\mathrm{NO}_{\mathrm{x}}$ by propene $\left(\mathrm{NO}_{\mathrm{x}}+\mathrm{x} / 9 \mathrm{C}_{3} \mathrm{H}_{6} \rightarrow \frac{1}{2} \mathrm{~N}_{2}+\mathrm{x} / 3 \mathrm{CO}_{2}+\mathrm{x} / 3 \mathrm{H}_{2} \mathrm{O}\right)$.

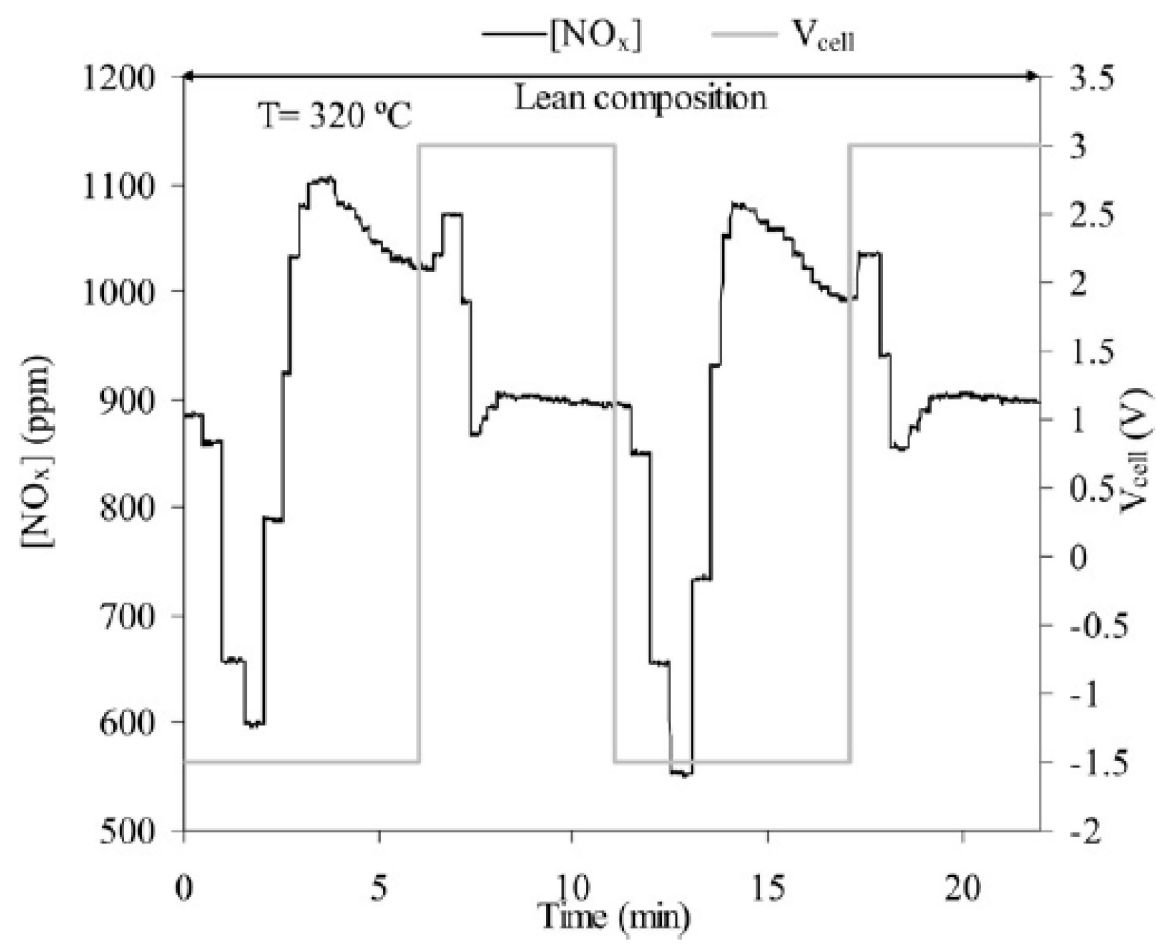

Figure 3. $\mathrm{NO}_{\mathrm{x}}$ outlet concentration profile vs. time during $\mathrm{NO}_{\mathrm{x}}$ storage/reduction experiments with a $\mathrm{Pt} / \mathrm{K}^{+}-\beta^{\prime \prime} \mathrm{Al}_{2} \mathrm{O}_{3}$ electrochemical catalyst under a fixed lean reaction composition $\left(\mathrm{NO} / \mathrm{C}_{3} \mathrm{H}_{6} / \mathrm{O}_{2}\right.$ : $1100 \mathrm{ppm} / 1000 \mathrm{ppm} / 5 \%$, He balance) at $320^{\circ} \mathrm{C}$. $\mathrm{NO}_{\mathrm{x}}$ storage step: $-1.5 \mathrm{~V}, \mathrm{NO}_{\mathrm{x}}$ reduction step: $+3 \mathrm{~V}$. Reprinted with permission from [86].

In the second study [87], a tubular configuration with larger exposed catalyst surface was developed, where both electrodes (working and counter) were made of $\mathrm{Pt}$ by the deposition and decomposition of organometallic pastes. The idea was to perform NSR under constant simulated lean-burn conditions, in a way that upon polarization, while one of the electrodes allowed for the NO oxidation and storage in the form of nitrates, the other electrode performed the decomposition and reduction of previously stored nitrates. The application of an opposed polarization led to the inversed catalytic/electro-catalytic processes in each electrode. Very interestingly, in Figure 4 one can observe that part of the produced $\mathrm{CO}_{2}$ was also stored on the catalyst, most likely in form of potassium carbonates. The latter are formed and decomposed under negative and positive polarization, respectively. 

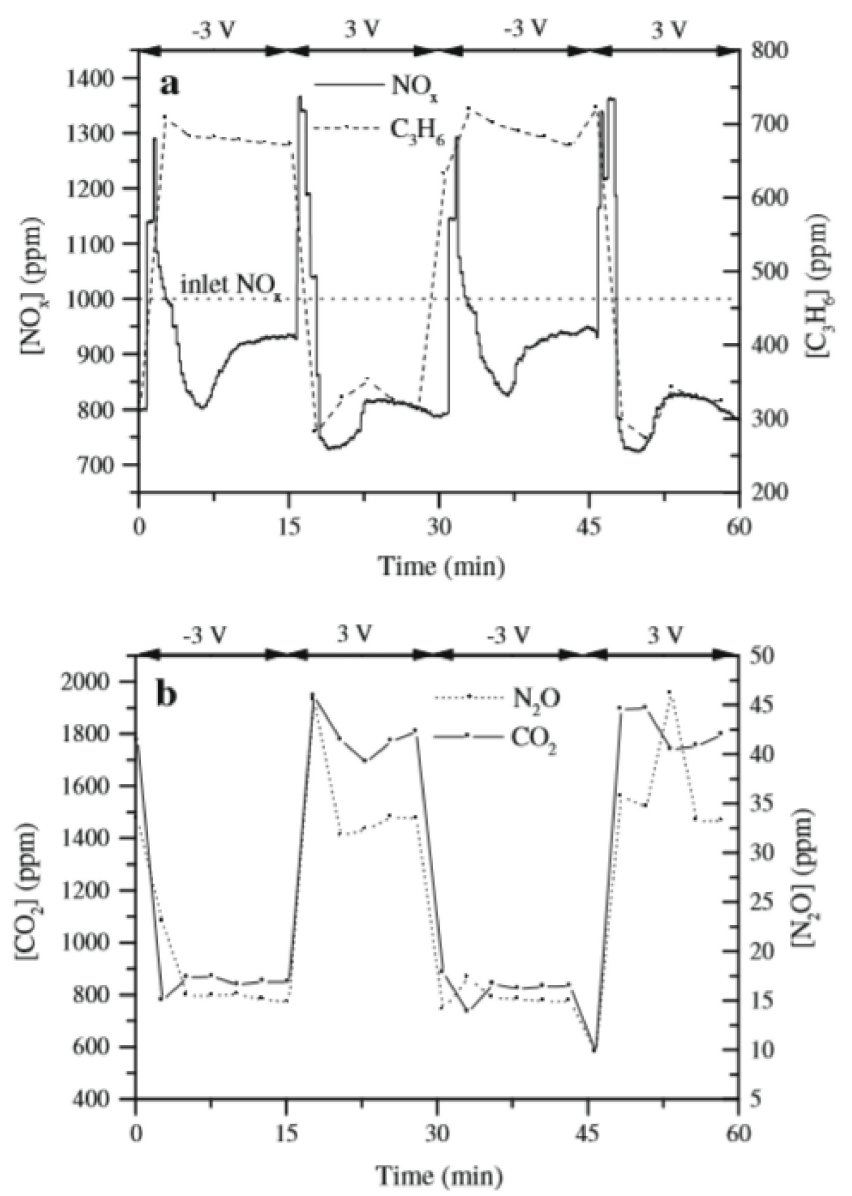

Figure 4. $\mathrm{NO}_{\mathrm{x}}, \mathrm{C}_{3} \mathrm{H}_{6}(\mathbf{a}), \mathrm{N}_{2} \mathrm{O}$ and $\mathrm{CO}_{2}(\mathbf{b})$ outlet concentration profiles vs. time during $\mathrm{NO}_{\mathrm{x}}$ storage/reduction tests with a tubular $\mathrm{Pt} / \mathrm{K}^{+}-\beta^{\prime \prime} \mathrm{Al}_{2} \mathrm{O}_{3} / \mathrm{Pt}$ electrochemical reactor. Fixed lean reaction conditions: $1000 \mathrm{ppm} \mathrm{NO}, 1000 \mathrm{ppm}_{3} \mathrm{H}_{6}, 5 \% \mathrm{O}_{2}$ (He balance), $320{ }^{\circ} \mathrm{C}$. $\mathrm{NO}_{\mathrm{x}}$ storage step: $-3 \mathrm{~V}, \mathrm{NO}_{\mathrm{x}}$ reduction step: $+3 \mathrm{~V}$. Reprinted with permission from [87].

These two studies demonstrate the possibility to perform the NSR process under constant lean-burn conditions. Therefore, no penalty due to the short fuel injections takes place, which could be translated into a significant positive economic impact. The electrochemically controlled dose of $\mathrm{K}^{+}$ions behaves, at the same time, as electronic promoters (EPOC) and as $\mathrm{NO}_{\mathrm{x}}$ adsorption sites (electro-catalysis). Both phenomena are uniquely favored in the same direction and they can be easily in-situ optimized by controlling the $\mathrm{K}^{+}$loading via the potential and the duration of the polarization. These features are not possible with conventional catalytic systems, then justifying the development of this EPOC approach for the removal of $\mathrm{NO}_{\mathrm{x}}$ by the NSR technology. One may think that the application of electrical potentials, however, might have an economic impact on this technology. Nevertheless, as opposed to the YSZ solid electrolytes previously explained (Section 2), $\mathrm{K}^{+}$does not behave as a sacrificial promoter, since it is not consumed during the chemical processes. Hence, upon the application of an electrical potential, once the necessary amount of $\mathrm{K}^{+}$species is supplied to or from the catalyst, the electrical current becomes negligible. In practical terms, this implies that the applied electrical power is negligible after a short polarization period. Of course, these studies showed the proof-of-concept of this technology, but they are far from being optimized and competitive regarding the current catalytic NSR systems. The following issues should be considered in view of the further practical implementation of this NSR approach:

As for the Ag catalysts previously described for the EO production, the Pt catalyst consists of a thick layer prepared by the thermal decomposition of organometallic paste precursors with a 
poor metallic dispersion (and therefore much lower overall catalytic activity) compared to that of commercial catalysts.

$\checkmark$ Even if a tubular configuration with higher exposed catalyst area was used in the second study [87], the catalytic reactor should be further improved and optimized, considering this catalyst would be ultimately introduced in the exhaust of a vehicle (with limited space).

As in Section 2.2, recent advances in EPOC technology must be highlighted regarding these issues. Prior the catalyst deposition on the $\mathrm{K}^{+} / \mathrm{Na}^{+}-\mathrm{BAl}_{2} \mathrm{O}_{3}$ solid electrolyte, the metallic phase could be easily dispersed on an electronic conductor (perovskites, $\mathrm{Co}_{3} \mathrm{O}_{4}, \mathrm{TiO}_{2}$, carbon nanofibers, diamond-like carbon, etc.) [21-25]. The catalyst film could also be arranged in the form of nanoporous electrodes to increase its specific surface area [30,31]. On the other hand, some particular types of monolithic reactors [88,89] and, specially, the MEPR reactors mentioned above [37,38], are very promising candidates to scale-up this EPOC application. Indeed, these reactors have been already tested under real conditions for the exhaust of automotive engines, which means that they are prepared to overcome important technical constraints, including the space management together with mechanical and thermal stability after a prolonged operation at high flow rates. All in all, the EPOC-assisted NSR approach developed in these studies potentially offers unique technological and economic features compared to the traditional NSR technology, and we believe that it could eventually constitute an industrial practical application of the EPOC systems. Table 2 summarizes the main features of the EPOC approach discussed in this section.

Table 2. Main issues and benefits of the EPOC-assisted NOx storage and reduction.

\begin{tabular}{|c|c|}
\hline \multicolumn{2}{|c|}{ The Case of EPOC-Assisted $\mathrm{NO}_{\mathrm{x}}$ Storage and Reduction (NSR) } \\
\hline \multirow{2}{*}{ Conventional catalysts } & Issues \\
\hline & Need of rich cycles for $\mathrm{NO}_{x}$ reduction: fuel penalty \\
\hline \multirow{7}{*}{ EPOC approach } & Benefits \\
\hline & NSR under constant lean-burn conditions: no fuel penalty \\
\hline & Low power-input \\
\hline & in-situ optimization of promoted state by applied polarization \\
\hline & Issues \\
\hline & Non-optimized Pt catalyst: low dispersion $=$ low activity \\
\hline & Reactor design \\
\hline
\end{tabular}

\section{The Case of $\mathrm{H}_{2}$ Production by Catalytic Reforming}

\subsection{Industrial Catalysts for $\mathrm{CH}_{4}$ Steam Reforming: Issues and Challenges}

$\mathrm{H}_{2}$ is an excellent energy carrier [90] and is expected to play a key role in future energy systems, such as fuel cells [91,92]. These devices can convert the chemical energy of $\mathrm{H}_{2}$ and air into clean electrical energy with a thermodynamic efficiency of $100 \%$. This explains why $\mathrm{H}_{2}$-fuel cell devices have become of paramount importance for dynamic and stationary applications [93,94].

Hydrogen can be produced from a wide variety of catalytic processes employing mainly nickeland cobalt-based catalysts, like steam reforming of different carbon feedstocks (e.g., methane, methanol, ethanol, acetic acid) [95-97], methane dry reforming [98,99], partial oxidation of methane and other hydrocarbons [95,100] or biomass gasification [101]. For economic and technical reasons, steam reforming of natural gas (mainly composed of methane, $\mathrm{CH}_{4}$ ) using Ni-based catalysts (usually supported on $\mathrm{Al}_{2} \mathrm{O}_{3}$ ) remains the preferred route for industrial hydrogen production [102,103]. This is a highly endothermic process usually performed at high reaction temperatures $\left(>700^{\circ} \mathrm{C}\right)$ producing a gas stream of $\mathrm{H}_{2}$, together with $\mathrm{CO}$ and $\mathrm{CO}_{2}$, by the reaction of natural gas with water (steam): $\mathrm{CH}_{4}+$ $\mathrm{H}_{2} \mathrm{O}_{\mathrm{v}} \rightarrow \mathrm{CO}+3 \mathrm{H}_{2}$, followed by water-gas shift: $\mathrm{CO}+\mathrm{H}_{2} \mathrm{O}_{\mathrm{v}} \rightarrow \mathrm{CO}_{2}+\mathrm{H}_{2}$ and/or $\mathrm{CO}$ oxidation: 
$\mathrm{CO}+\frac{1}{2} \mathrm{O}_{2} \rightarrow \mathrm{CO}_{2}$. However, Ni-based catalysts are prone to sintering at high temperature in the presence of steam, and suffering from carbon deposition (coking process), which might result in their deactivation during the reaction. As an alternative, these catalysts can be promoted by alkalis (mainly potassium) [104-106] to improve their resistance to coking, enhancing therefore their stability due to the enhanced chemisorption of water. However, the addition of potassium promoters decreases the Ni specific activity. Therefore, one of the main challenges is to develop a highly active and stable catalytic material. EPOC can be used to electrochemically control and optimize the potassium loading on the catalyst surface.

\subsection{Discussion on Dynamic EPOC Studies on Catalytic Steam Reforming with Alkaline Promoters}

The electrochemical promotion of the $\mathrm{H}_{2}$ production with alkali promoters was recently reviewed [17]. Most of the reported studies deal with steady-state processes, where the catalytic activity is enhanced by the electrochemical addition of alkali promoters. A study [107] on the catalytic reforming of methane is particularly interesting. A Pt/YSZ composite layer was deposited on a $\mathrm{Na}^{+}-\mathrm{\beta Al}_{2} \mathrm{O}_{3}$ solid electrolyte membrane. This electrochemical catalyst was tested under steam reforming conditions ( $\mathrm{SR}, 1 \% \mathrm{CH}_{4}, 4 \% \mathrm{H}_{2} \mathrm{O}$ ), together with auto-thermal reforming conditions (ATR, $1 \% \mathrm{CH}_{4}, 4 \% \mathrm{H}_{2} \mathrm{O}$, $2000 \mathrm{ppm} \mathrm{O}_{2}$ ). Auto-thermal reforming is a commonly used alternative to steam reforming [108], where the endothermicity of the later is counterbalanced by the exothermicity of the methane partial oxidation reaction $\left(\mathrm{CH}_{4}+\frac{1}{2} \mathrm{O}_{2} \rightarrow 2 \mathrm{H}_{2}+\mathrm{CO}\right)$. Figure 5 depicts a cyclic experiment upon step changes in the applied potential from negative $(-1 \mathrm{~V})$ to positive $(+2 \mathrm{~V})$ polarizations under autothermal reforming conditions at $500{ }^{\circ} \mathrm{C}$.

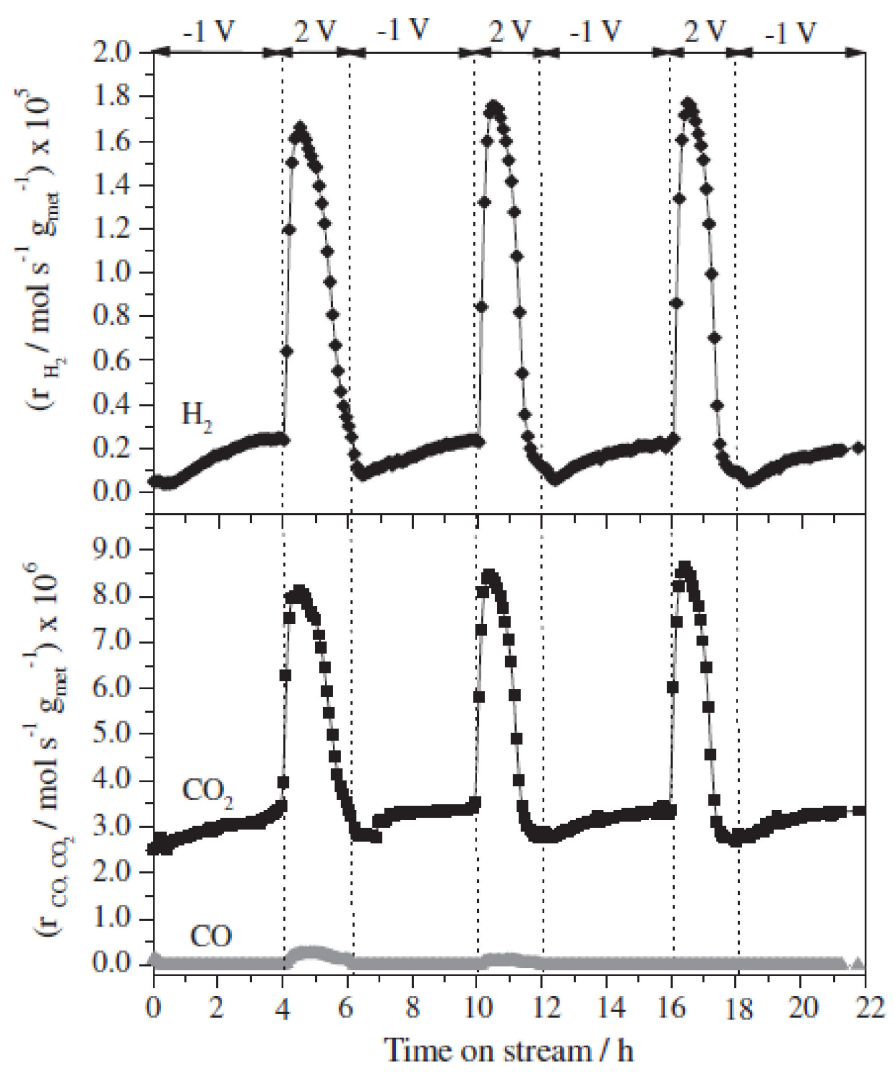

Figure 5. $\mathrm{H}_{2}, \mathrm{CO}$ and $\mathrm{CO}_{2}$ molar flow rates vs. time during a cycling deactivation/regeneration experiment with a Pt-YSZ/Na ${ }^{+}-\beta^{\prime \prime} \mathrm{Al}_{2} \mathrm{O}_{3}$ electrochemical catalyst. Fixed methane autothermal reforming reaction conditions: $1 \% \mathrm{CH}_{4}, 4 \% \mathrm{H}_{2} \mathrm{O}, 0.2 \% \mathrm{O}_{2}\left(\mathrm{~N}_{2}\right.$ balance), $500{ }^{\circ} \mathrm{C}$. Catalyst deactivation step: $+2 \mathrm{~V}$. Catalyst regeneration step: $-1 \mathrm{~V}$. Reprinted with permission from [107]. 
As expected, $\mathrm{H}_{2}$ and $\mathrm{CO}_{2}$ were the main observed products (along with traces of $\mathrm{CO}$ ). Under the application of negative polarizations, the activity was low but stable. However, under the application of positive potentials, the performance reached to a maximum, and then abruptly decreased. This could be rationalized based on the rules of EPOC with alkali promoters. As previously explained in Section 3.2, upon negative polarizations the alkaline ions spilled-over to the Pt-based catalyst. In a similar way than that for conventional catalysts, these promoters can enhance the chemisorption of electron-donor species, in this case water (and $\mathrm{O}_{2}$ ), decreasing the coking phenomenon. This leads to a high stability but a low activity. However, upon positive polarizations, the sodium ions are forced to migrate back to the solid electrolyte. Higher reforming performance and coking activity are expected under these conditions, leading to a significant deactivation, as is also the case in conventional un-promoted catalysts. Nevertheless, the catalyst surface can be regenerated upon the application of negative polarizations, since the enhanced chemisorption of water or $\mathrm{O}_{2}$ allowed for oxidizing the previously deposited carbon. Therefore, this kind of polarized electrochemical catalysts can be operated cyclically by varying the applied potential and the polarization period to optimize the activity.

Such dynamic cyclic operation mode (promoted/un-promoted/promoted ... ) and in-situ optimization features are not possible with conventional catalysts. Therefore, the use of EPOC catalysts is completely justified, since this approach can take advantage of both, promoted and un-promoted catalysts for methane reforming. In spite of that, this system is far from being optimized. The following issues should be considered in view of its further practical implementation:

$\checkmark$ A Pt-based composite layer was used as a catalyst. This metal exhibits high cost compared to Ni and a much lower dispersion than conventional catalysts.

$\checkmark$ A proper reactor design should be developed to substitute the current methane reformers by EPOC technologies.

Thus, the first upgrade strategy could be to substitute Pt catalyst by non-noble metals ( $\mathrm{Fe}, \mathrm{Ni}$, $\mathrm{Cu}$ ). As suggested in Section 3.2 for NSR, other catalyst preparation methods, by using an electronic conductor matrix, are also required in order to increase the metallic dispersion and to enhance the activity of the electrochemical catalyst. Regarding the reactor design, either the multi-pellet reactor or the monolithic reactor configurations could make possible the short/mid-term scale-up of the EPOC approach for methane steam reforming.

On the other hand, some other EPOC studies were also focused on the catalytic decomposition/partial oxidation/steam reforming of methanol as an alternative to the methane steam reforming. For instance, Gonzalez-Cobos et al. [31] described a novel Ni/ $\mathrm{K}^{+}-\mathrm{All}_{2} \mathrm{O}_{3}$ electrochemical catalyst, with highly dispersed nickel nanocolumnar films of controlled microstructure, prepared by oblique angle physical vapor deposition. This very innovative work dealt, using EPOC, not only with $\mathrm{H}_{2}$ production but also with $\mathrm{H}_{2}$ storage (simultaneously). Figure 6 shows a schematic of the proposed mechanism and an example of a dynamic experiment on $\mathrm{H}_{2}$ production/storage and release. Under a methanol steam reforming reaction atmosphere $\left(\mathrm{CH}_{3} \mathrm{OH} / \mathrm{H}_{2} \mathrm{O}=4.4 \% / 5.2 \%\right)$, the activity towards the production of $\mathrm{H}_{2}$ was enhanced at $280^{\circ} \mathrm{C}$ under the application of negative polarizations, due to the spill-over of potassium ions towards the catalyst surface [109], followed by a strong deactivation. The most interesting result dealt with the dynamic storage of the $\mathrm{H}_{2}$ produced at these negative potentials. Microscopy (SEM) and spectroscopic techniques (FTIR and Raman) confirmed the presence of carbonaceous species (hypothetically identified as graphene oxide) produced during the electrochemically promoted methanol decomposition in the presence of $\mathrm{K}^{+}$promoters. Then, chemisorbed $\mathrm{H}$ atoms on $\mathrm{Ni}$ active sites could be stored on these carbonaceous compounds (Figure 6a), where the presence of $\mathrm{K}^{+}$ions could stabilize the hydrogen adsorption, as observed elsewhere when alkali ions were intercalated into graphitic layers [110]. In other words, $\mathrm{H}_{2}$ can be stored on the graphene oxide in the presence of potassium species. This explains why, upon the application of positive polarizations, $\mathrm{H}_{2}$ is desorbed and released under inert atmosphere, as it can be observed in Figure $6 \mathrm{~b}$. It should be noted that the in-situ controlled $\mathrm{K}^{+}$supply and the formation of graphene-like 
species on the surface of this nanoporous $\mathrm{Ni} / \mathrm{K}^{+}-\beta \mathrm{Al}_{2} \mathrm{O}_{3}$ electrochemical catalyst has been proved by Espinós et al. in two recent studies by in operando near-ambient pressure photoemission (NAPP) spectroscopy $[111,112]$.

a

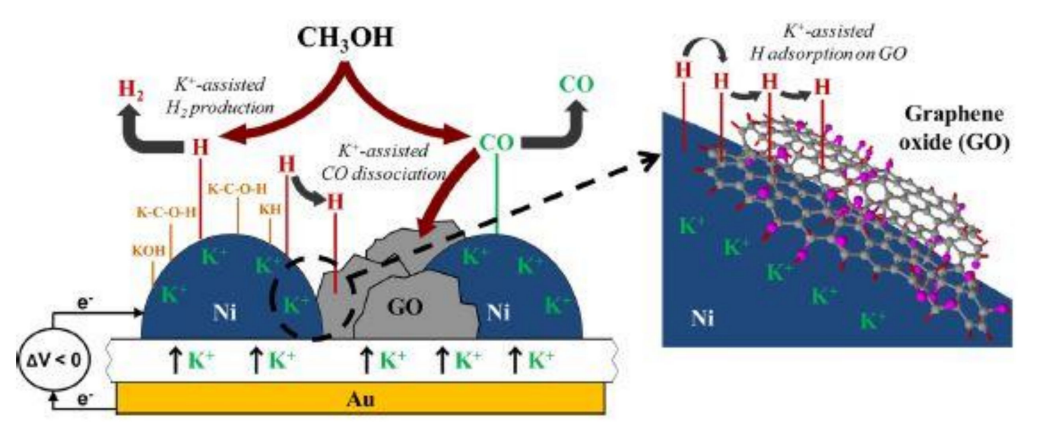

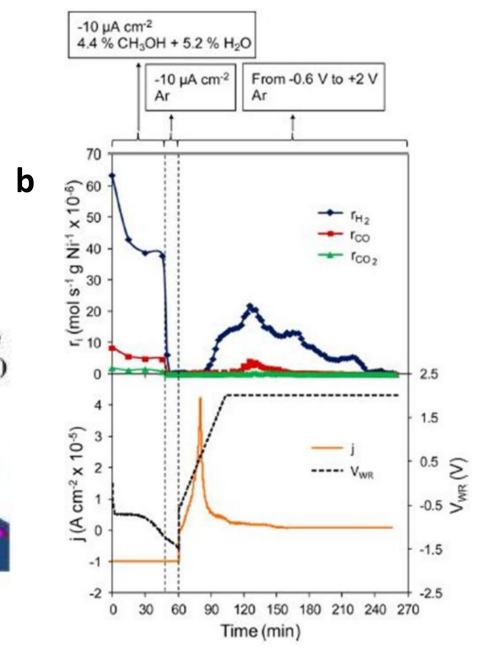

Figure 6. Potassium-promoted $\mathrm{H}_{2}$ production and storage mechanism with a Ni/K+ $\mathrm{K}^{+}-\beta^{\prime \prime} \mathrm{Al}_{2} \mathrm{O}_{3}$ electrochemical catalyst (a). Profiles of current density (j), catalyst potential $\left(\mathrm{V}_{\mathrm{WR}}\right), \mathrm{H}_{2}, \mathrm{CO}$ and $\mathrm{CO}_{2}$ molar flow rates vs. time during a $\mathrm{H}_{2}$ storage experiment at $1 \mathrm{~atm}$ and $280^{\circ} \mathrm{C}(\mathbf{b}) . \mathrm{H}_{2}$ production/storage step: $\mathrm{CH}_{3} \mathrm{OH} / \mathrm{H}_{2} \mathrm{O}=4.4 \% / 5.2 \%$ (Ar balance), $\mathrm{j}=-10 \mu \mathrm{A}$. Cleaning step: $100 \% \mathrm{Ar}, \mathrm{j}=-10 \mu \mathrm{A} . \mathrm{H}_{2}$ release step: $100 \% \mathrm{Ar}$, linear sweep voltammetry from $-0.6 \mathrm{~V}$ to $+2 \mathrm{~V}\left(1 \mathrm{mV} \mathrm{s}^{-1}\right)$. Reprinted with permission from [31].

The main weakness of this EPOC approach on hydrogen production/storage is its complexity since it involves not only the catalyst film and the solid electrolyte but also the carbonaceous species generated during the methanol reforming reaction. Further studies should be carried out to better understand the different processes taking place, for example by using model catalysts containing controlled graphene-like deposits to directly focus on the $\mathrm{H}_{2}$ storage and release stages. However, this previously presented study reports a drastically new proof of concept where both, the production and storage of $\mathrm{H}_{2}$, are enhanced in the presence of $\mathrm{K}^{+}$ions. The maximum hydrogen storage capacity obtained was c.a. $19 \mathrm{wt} . \% \mathrm{H}_{2}$ with respect to catalyst loading [31], which outperforms that of the best metal hydrides used for $\mathrm{H}_{2}$ storage (i.e., $\mathrm{LiBH}_{4}$ with $18 \mathrm{wt} . \% \mathrm{H}_{2}$ ). In addition, the proposed system is able to operate $\left(\mathrm{H}_{2}\right.$ adsorption/desorption) under fixed and mild conditions $\left(280^{\circ} \mathrm{C}\right.$ and $\left.1 \mathrm{~atm}\right)$ unlike all conventional storage methods $[113,114]$. The $\mathrm{H}_{2}$ release can be controlled by the polarization. From the technological point of view, the upgrade degree of the materials employed to explore this EPOC approach was already quite high. However, the unavoidable electrochemical-cell-like configuration still stands as a bottle neck for the scale-up of this EPOC application and the proper reactor design (like the MEPR configuration) should be implemented. Table 3 summarizes the main features of the EPOC approaches discussed in this section. 
Table 3. Main issues and benefits of the EPOC-assisted methane and methanol steam reforming.

\begin{tabular}{|c|c|}
\hline \multicolumn{2}{|c|}{ The Case of EPOC-Assisted Catalytic Reforming } \\
\hline \multirow{3}{*}{ Conventional catalysts } & Issues \\
\hline & No promotion: carbon deposition by coking \\
\hline & Promotion by alkalis: low activity \\
\hline \multirow{9}{*}{$\begin{array}{l}\text { EPOC approach } \\
\text { Methane reforming }\end{array}$} & Benefits \\
\hline & Cyclic operation by step changes in applied polarization \\
\hline & Unpromoted conditions $=$ high activity + coking $($ deactivation $)$ \\
\hline & Promoted conditions $=$ low activity + regeneration \\
\hline & $\begin{array}{l}\text { in-situ optimization of promoted/unpromoted states in cyclic } \\
\text { polarisation mode }\end{array}$ \\
\hline & Issues \\
\hline & Non-optimized Pt catalyst: low dispersion $=$ low activity \\
\hline & Use of $\mathrm{Pt}$, while conventional catalysts are based on $\mathrm{Ni}$ \\
\hline & Reactor design \\
\hline \multirow{9}{*}{$\begin{array}{c}\text { EPOC approach } \\
\text { Methanol reforming } \\
\mathrm{H}_{2} \text { storage/release }\end{array}$} & Benefits \\
\hline & $\begin{array}{l}\text { Capability of simultaneous } \mathrm{H}_{2} \text { production and storage via graphene-like } \\
\text { surface compounds }\end{array}$ \\
\hline & Promoted conditions $=$ high activity + controlled $\mathrm{H}_{2}$ storage \\
\hline & Unpromoted conditions $=$ controlled $\mathrm{H}_{2}$ release \\
\hline & $\begin{array}{l}\text { Cyclic operation via applied polarization at mild temperature and } \\
\text { atmospheric pressure }\end{array}$ \\
\hline & Development of advanced Ni catalysts with high dispersion \\
\hline & Issues \\
\hline & Reactor design \\
\hline & Complexity of the $\mathrm{H}_{2}$ storage system \\
\hline
\end{tabular}

\section{Coupling Electrolysis and EPOC}

Together with catalytic reforming technologies, the water electrolysis process has gained growing attention lately since it allows for a fast, controlled, modular, and convenient production of pure $\mathrm{H}_{2}$ in one step. Water electrolysis is an electro-catalytic process, in which the water molecule splits into pure $\mathrm{H}_{2}$ and $\mathrm{O}_{2}$ gases under the application of an electrical potential between two electrodes. Using renewable electrical energy, electrolysers produce green hydrogen. Water electrolysis is usually operated in fuel cell-type reactors either at low temperature $\left(<90^{\circ} \mathrm{C}\right)$ in proton-exchange membrane (PEM) electrolysers $[115,116]$ or at high temperatures $\left(500-1000{ }^{\circ} \mathrm{C}\right)$ in solid oxide electrolysers (SOE) $[115,117,118]$. However, the hydrogen production via electrolysis is not economically competitive compared to catalytic reforming processes. The thermodynamic potential to electrolyze water in a PEM electrolyser ( $1.23 \mathrm{~V}$ at room temperature) is demanding for the stability of materials and in terms of energy consumption. To overcome this problem, organic molecules can be introduced at the anode instead of $\mathrm{H}_{2} \mathrm{O}$ to depolarize the electrolysers for onsite pure $\mathrm{H}_{2}$ production [22,119-131]. Indeed, the electro-oxidation of the organic molecules is thermo-dynamically favored compared to the water electrolysis process (by 1-2 orders of magnitude, depending on the organic molecule). However, the kinetics of the electro-oxidation of organic molecules below $90^{\circ} \mathrm{C}$ remains slow even on Pt-based electrodes. Regarding SOE, high temperatures dramatically enhance the kinetics for the electrochemical reactions [132]. However, working at such high temperatures is challenging regarding the development of stable and robust materials (due to the chemical compatibility between electrodes 
and electrolyte, sealing materials, etc.). One solution to lower the electrolysis cost could be to combine this technology with EPOC. PEM electrolysers and SOE technologies are mature, easy to scale up in stacks, allowing to polarize a catalyst-electrode and then to implement EPOC. The idea, recently proposed in the literature $[133,134]$, is to couple the electrolysis process with an electropromoted catalytic reaction at the cathode that can produce extra hydrogen.

\subsection{EPOC in Solid Oxide Electrolysers}

A pioneering study at University of Castilla-La Mancha in Ciudad Real (Spain) has proposed to operate methane steam reforming in a SOE [133]. Experiments were performed in a single chamber reactor, $\mathrm{Pt}-\mathrm{YSZ}_{\text {composite }} / \mathrm{YSZ} / \mathrm{Au}$ (cathode/solid electrolyte/anode). The reactor and the composite (cathode) were similar to those of the previously described study (Section 3, methane steam reforming [107]). The idea of this study was to explore, for the first time, the possibility to couple the steam electrolysis process for $\mathrm{H}_{2}$ production with the catalytic steam/autothermal reforming of methane enhanced via EPOC. Figure 7 shows one of the most representative experiments to demonstrate this novel approach. The activity of the system was studied under three different reaction atmospheres: steam electrolysis (SE, in the presence of $\mathrm{H}_{2} \mathrm{O} / \mathrm{O}_{2}: 1.5 \% / 0.2 \%$ ), methane partial oxidation ( $\mathrm{POX}: \mathrm{CH}_{4} / \mathrm{O}_{2}$ : $1 \% / 0.2 \%$ ), and auto-thermal methane reforming (ATR, $\mathrm{CH}_{4} / \mathrm{H}_{2} \mathrm{O} / \mathrm{O}_{2}: 1 \% / 1.5 \% / 0.2 \%$ ).

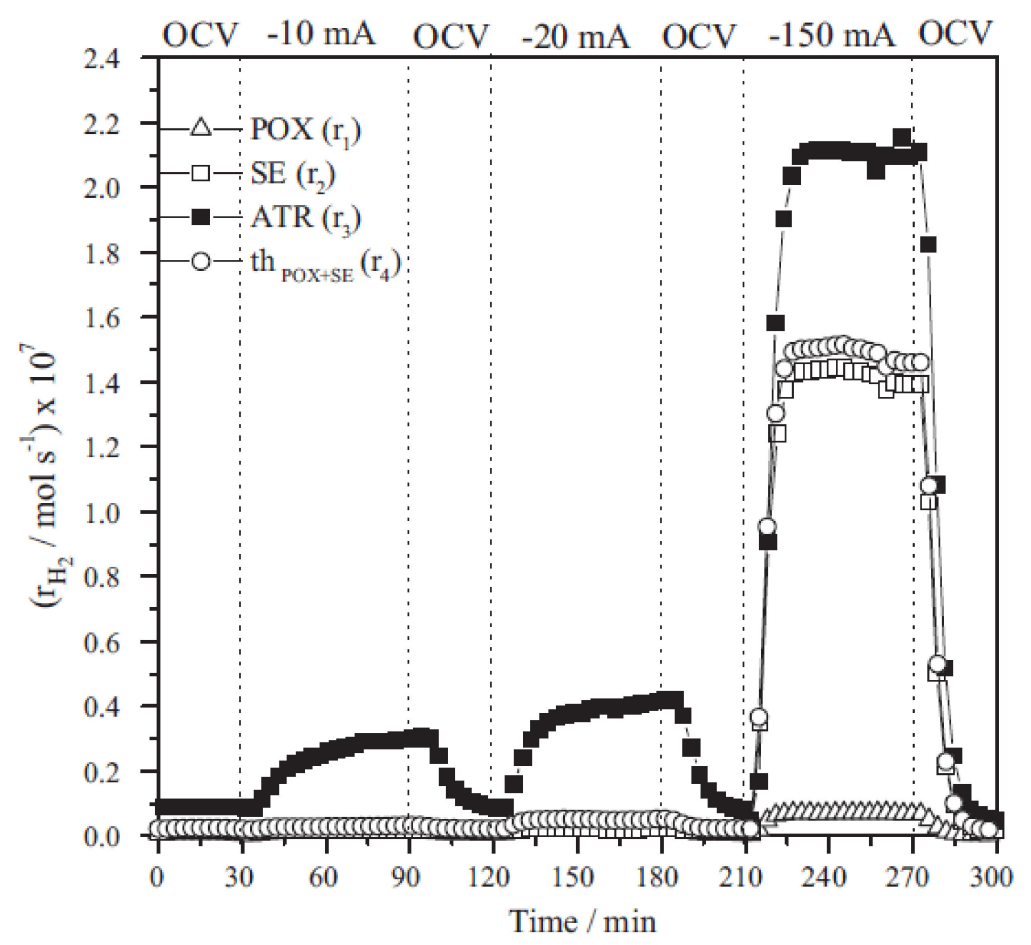

Figure 7. $\mathrm{H}_{2}$, molar flow rates vs. time during different galvanostatic transitions with a Pt-YSZ/YSZ electrochemical catalyst at $600{ }^{\circ} \mathrm{C}$ and under different reaction atmospheres: $1 \% \mathrm{CH}_{4} / 0.2 \% \mathrm{O}_{2}$ (POX), $1.5 \% \mathrm{H}_{2} \mathrm{O} / 0.2 \% \mathrm{O}_{2}$ (SE) and $1 \% \mathrm{CH}_{4} / 1.5 \% \mathrm{H}_{2} \mathrm{O} / 0.2 \% \mathrm{O}_{2}$ (ATR). The joint contribution of POX and SE, th $\mathrm{POX}_{+\mathrm{SE}}$, is also depicted for comparison vs. ATR. Reprinted with permission from [133].

As expected, in the case of steam electrolysis, the application of negative polarizations led to the electro-reduction of water at the Pt-YSZ composite, with the subsequent production of $\mathrm{H}_{2}$ and $\mathrm{O}^{2-}$ species. Under the methane partial oxidation conditions, the activity was negligible even upon polarization due to the absence of steam. The most interesting results were obtained under auto-thermal reforming conditions. Under open circuit conditions, the production of $\mathrm{H}_{2}$ was negligible, but upon the application of several negative polarizations, the production of hydrogen drastically increased. The $\mathrm{H}_{2}$ production was much higher than for SE + POX. This clearly points out that the steam 
electrolysis process (electrocatalysis) was coupled with a catalytic process. The addition of methane to the solid oxide electrolyser leads to an additional production of $\mathrm{H}_{2}$ due to the electropromoted catalytic reforming of methane. However, the $\mathrm{H}_{2}$ production was lower than that predicted by the Faraday's law because the electrolysis was operated in a single-chamber reactor, owing to the partial recombination of $\mathrm{H}_{2}$ with some of the $\mathrm{O}_{2}$ present in the reaction atmosphere. It could be very promising to test this novel approach in a double chamber SOE. On the other hand, a Pt catalyst was used as cathode in this study, in contrast to conventional SOE steam electrolysers where materials with mixed ionic $\left(\mathrm{O}^{2-}\right)$ /electronic conductivity are commonly employed, generally Ni/YSZ (cathode) and perovskite (anode) electrodes. Ideally, considering that $\mathrm{Ni}$ is the state-of-the-art material for $\mathrm{CH}_{4}$ catalytic reforming, the commercially available electrochemical catalysts used for SOE steam electrolysis should also exhibit high performance for the EPOC-assisted electrolyser and they would not have to be modified for this new EPOC approach. For example, this EPOC approach could be studied on nanoporous Ni/YSZ-based materials like those reported in literature which were prepared by PVD in oblique angle [135-137].

\subsection{EPOC in Depolarized PEM Electrolysers}

Our group in collaboration with the University of Castilla-La Mancha recently operated EPOC in a low temperature methanol/water electrolyser with $\mathrm{Pt}-\mathrm{C} /\left(\mathrm{OH}^{-}\right.$-polymeric membrane $) / \mathrm{Pd}-\mathrm{C}$ (anode/electrolyte/cathode). Methanol was used as a model representative of alcohol molecules [134]. In this case, instead of a SOE electrolyser, we used a polymer electrolyte membrane (PEM) configuration. Analogously to the previous study, the idea was to couple the electrolysis process with the catalytic methanol decomposition reaction at the cathode. Therefore, we introduced methanol not only in the anode but also in the cathode.

Figure 8a displays that the production of $\mathrm{H}_{2}$ in the novel approach exceeded the values predicted by the Faraday's law (i.e., those obtained in a conventional methanol/water electrolyser). The overproduction of $\mathrm{H}_{2}$ was attributed to the catalytic methanol decomposition on $\mathrm{Pd}$. In addition, no $\mathrm{H}_{2}$ production was observed under open circuit conditions, meaning that this catalytic reaction was electropromoted. We concluded that the electropromoted methanol decomposition was combined with the water electrolysis which was found not to be affected by the presence of methanol in the cathode (Figure 8b). This innovative process could lower the cost of the $\mathrm{H}_{2}$ produced in alcohol/water electrolysers. However, as in the previous case, noble metal-based electrodes were used for both, anode and cathode. In order to be competitive with current water electrolysis technologies, similar $\mathrm{Ni}$-based electrodes to those commercially available should be tested for the EPOC-assisted technology presented in this article.

Regarding the reactor design and scale-up, it should not be an important issue in these cases. As a matter of fact, the main advantage of these EPOC-electrolysis approaches is that they would potentially improve current electrochemical technologies: high temperature steam electrolysis in SOE and low temperature electrolysis in PEM reactors. Both, SOE and PEM water electrolysers are in a very advanced development state, and nowadays scale-up stack reactors can be acquired commercially for real applications [136]. Thus, the electrolysis/EPOC coupling offered a new approach where, for the first time, the EPOC phenomenon could be straightforwardly applied. We believe that this could constitute a break-through technology to enhance the " $\mathrm{H}_{2}$ economy". 

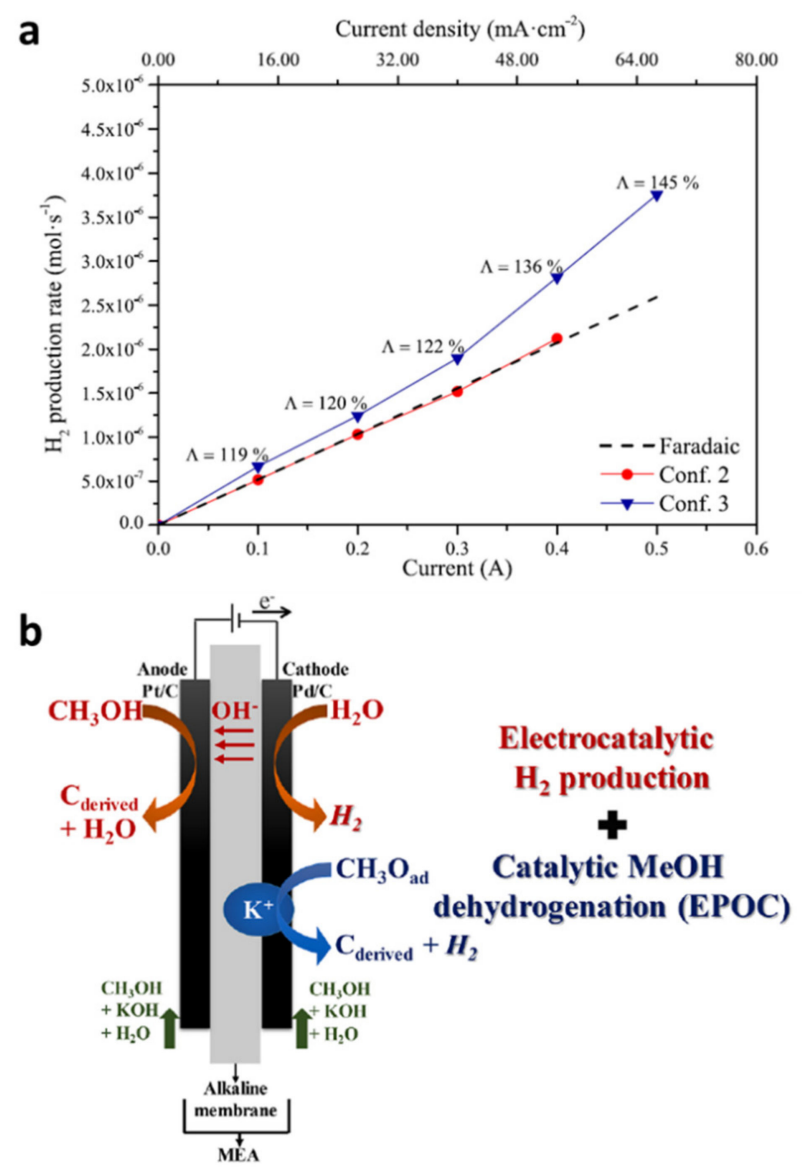

Figure 8. Steady-state $\mathrm{H}_{2}$ production rate under different chronopotentiometries with a Pt-C/(Fumapem FAA-3-50) membrane/Pd-C electrolysis cell along with predicted faradaic $\mathrm{H}_{2}$ production rate (a). Two operation modes: conventional electrolyser (conf. 2) where methanol is fed to the anode and water to the cathode, and EPOC-enhanced electrolyser (conf. 3) where methanol is also added in the cathode feed stream leading to additional catalytic $\mathrm{H}_{2}$ production via electrochemical promotion. The later configuration is schematized in (b). Reprinted with permission from [134].

Table 4 summarizes the main aspects discussed in this section.

Table 4. Main issues and benefits of the EPOC-assisted water and methanol electrolysis.

\begin{tabular}{|c|c|}
\hline & The Case of EPOC-Assisted Electrolysis \\
\hline \multirow{3}{*}{ Conventional catalysts } & Issues \\
\hline & Catalyst efficiency \\
\hline & Material durability and energy consumption costs \\
\hline \multirow{8}{*}{$\begin{array}{c}\text { EPOC approach } \\
\text { Solid oxide electrolysis } \\
\text { (Water electrolysis) }\end{array}$} & Benefits \\
\hline & Coupling of steam electrolysis (electrocatalysis) + methane reforming (EPOC) \\
\hline & Additional $\mathrm{H}_{2}$ production with the same power input = higher energy efficiency \\
\hline & Easy to scale-up by the use of state-of-the art SOE stack-electrolysers \\
\hline & in-situ optimization of promoted states by applied polarization \\
\hline & Issues \\
\hline & Non-optimized Pt catalyst: low dispersion = low activity \\
\hline & $\begin{array}{c}\text { Use of Pt, while conventional electrolysers are based on } \mathrm{Ni} \\
\text { Use of single chamber reactors instead of state-of-the art double chamber } \\
\text { configurations }\end{array}$ \\
\hline
\end{tabular}


Table 4. Cont.

\begin{tabular}{|c|c|}
\hline & The Case of EPOC-Assisted Electrolysis \\
\hline \multirow{7}{*}{$\begin{array}{c}\text { EPOC approach } \\
\text { Depolarized PEM electrolysers } \\
\text { (Methanol electrolysis) }\end{array}$} & Benefits \\
\hline & $\begin{array}{l}\text { Coupling of methanol electrolysis (electrocatalysis) + methanol decomposition } \\
\text { (EPOC) }\end{array}$ \\
\hline & Additional $\mathrm{H}_{2}$ production with the same power input = higher energy efficiency \\
\hline & Easy to scale-up by the use of state-of-the art PEM stack-electrolysers \\
\hline & in-situ optimization of promoted states by applied polarization \\
\hline & Issues \\
\hline & Use of noble metals, while conventional water electrolysers are based on $\mathrm{Ni}$ \\
\hline
\end{tabular}

After analyzing all these chemical processes where the use of EPOC could be completely justified, one can find some common issues to be addressed, as discussed in the introduction section, including: (i) the electrochemical promotion of dispersed metal nanoparticles (including non-noble metals) and (ii) the reactor development. Figure 9 summarizes the different developed materials and reactors that we propose to implement in view of the practical application of EPOC approach.

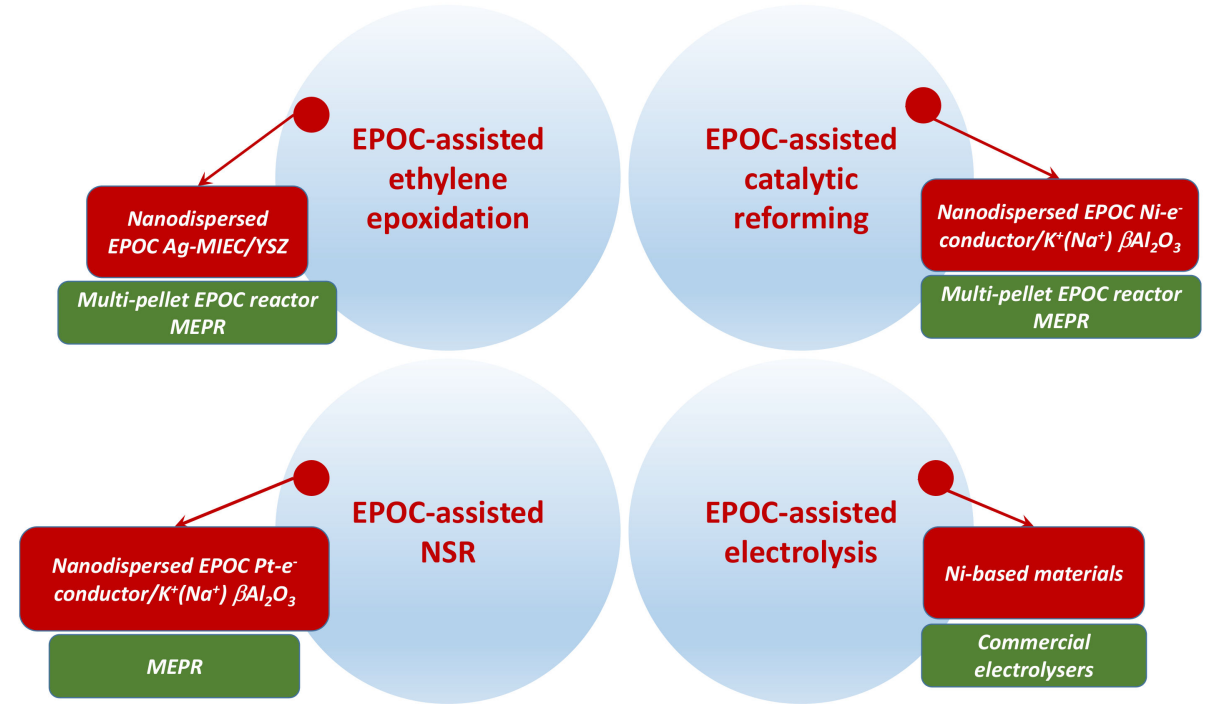

Figure 9. Most promising catalyst and reactor configurations for competitive scaled-up EPOC applications.

\section{Conclusions}

This review discusses different catalytic and electrocatalytic processes for which EPOC could offer a real added value. The various examples highlight the unique features of EPOC. First, EPOC is the only way to supply oxygen anionic promoters to a catalyst surface (as in the case of ethylene oxide production). Using alkaline ionic conductors $\left(\mathrm{Na}^{+}, \mathrm{K}^{+}\right)$, alternating positive and negative voltage pulses could control and improve the $\mathrm{NO}_{\mathrm{x}}$ storage and reduction as well as the production, the storage and the release of $\mathrm{H}_{2}$. In addition, a catalyst surface poisoned by coke deposition could be periodically and operando regenerated by the supply of cationic promoters triggered by short negative voltage pulses. Finally, EPOC can operate in high-temperature (SOE) and low-temperature depolarized electrolysers without any modification of the reactor and operation mode. For instance, the decomposition of methanol, introduced in the cathodic compartment of a PEM electrolyser, can be electropromoted to enhance the production of hydrogen and then improve the energy efficiency.

The proof of concept of these approaches was performed with standard/not-optimized materials, generally with low dispersion and therefore low specific activity compared to that of commercial 
systems. Novel catalysts with high dispersion and surface area are already developed for different EPOC technologies, like nanoporous electrodes and metal or metal oxide nanoparticles finely dispersed on either electron conductor matrix or mixed ion-electron conductor matrix. Also, to this date, several EPOC reactor designs have been successfully developed and tested under real conditions for different applications, like the multi-pellet and monolithic configurations. In the case of SOE and depolarized PEM electrolysers, both materials and reactors are in development and near a commercial stage. They could be straightforwardly tested for the upgraded EPOC approach in electrolysis. Future efforts should focus on testing the advanced materials in unique chemical processes where EPOC can offer outstanding benefits, such as the ones suggested in this article.

Author Contributions: A.C., J.G.-C. and P.V. designed the manuscript. All authors have read and agreed to the published version of the manuscript.

Funding: This study was performed within the "EPOX" project, funded by the French National Research Agency (ANR), ANR-2015-CE07-0026.

Conflicts of Interest: The authors declare no conflict of interest.

\section{References}

1. Nielsen, A. Review of Ammonia Catalysis. Catal. Rev. 1971, 4, 1-26. [CrossRef]

2. Jahangiri, H.; Bennett, J.; Mahjoubi, P.; Wilson, K.; Gu, S. A review of advanced catalyst development for Fischer-Tropsch synthesis of hydrocarbons from biomass derived syn-gas. Catal. Sci. Technol. 2014, 4, 2210-2229. [CrossRef]

3. Xu, H.; Zhu, L.; Nan, Y.; Xie, Y.; Cheng, D. Revisit the Role of Chlorine in Selectivity Enhancement of Ethylene Epoxidation. Ind. Eng. Chem. Res. 2019, 58, 21403-21412. [CrossRef]

4. Stoukides, M.; Vayenas, C.G. The effect of electrochemical oxygen pumping on the rate and selectivity of ethylene oxidation on polycrystalline silver. J. Catal. 1981, 70, 137-146. [CrossRef]

5. Vayenas, C.G.; Bebelis, S.; Neophytides, S. Non-faradaic electrochemical modification of catalytic activity. J. Phys. Chem. 1988, 92, 5083-5085. [CrossRef]

6. Vayenas, C.G. Thermodynamic analysis of the electrochemical promotion of catalysis. Solid State Ionics 2004, 168, 321-326. [CrossRef]

7. Tsiplakides, D.; Balomenou, S.; Katsaounis, A.; Archonta, D.; Koutsodontis, C.; Vayenas, C.G. Electrochemical promotion of catalysis: Mechanistic investigations and monolithic electropromoted reactors. Catal. Today 2005, 100, 133-144. [CrossRef]

8. Lintz, H.-G.; Vayenas, C.G. Solid Ion Conductors in Heterogeneous Catalysis. Angew. Chemie Int. Ed. English 1989, 28, 708-715. [CrossRef]

9. Vayenas, C.G. Bridging electrochemistry and heterogeneous catalysis. J. Solid State Electrochem. 2011, 15, 1425-1435. [CrossRef]

10. González-Cobos, J.; de Lucas-Consuegra, A. A review of surface analysis techniques for the investigation of the phenomenon of electrochemical promotion of catalysis with alkaline ionic conductors. Catalysts 2016, 6. [CrossRef]

11. De Lucas-Consuegra, A. New trends of alkali promotion in heterogeneous catalysis: Electrochemical promotion with alkaline ionic conductors. Catal. Surv. Asia 2015, 19, 25-37. [CrossRef]

12. Vernoux, P. Recent advances in electrochemical promotion of catalysis. In Catalysis; The Royal Society of Chemistry: London, UK, 2017; Volume 29, pp. 29-59. ISBN 9781782629566.

13. Vayenas, C.G. Promotion, electrochemical promotion and metal-support interactions: Their common features. Catal. Lett. 2013, 143, 1085-1097. [CrossRef]

14. Yentekakis, I.V.; Vernoux, P.; Goula, G.; Caravaca, A. Electropositive promotion by Alkalis or Alkaline earths of Pt-group metals in emissions control catalysis: A status report. Catalysts 2019, 9. [CrossRef]

15. Vayenas, C.; Bebeli, S.; Pliangos, C.; Brosda, S.; Tsiplakides, D. Electrochemical Activation of Catalysis: Promotion, Electrochemical Promotion, and Metal-support Interactions; Springer Science \& Business Media: New York, NY, USA, 2001. 
16. Vernoux, P.; Lizarraga, L.; Tsampas, M.N.; Sapountzi, F.M.; De Lucas-Consuegra, A.; Valverde, J.-L.; Souentie, S.; Vayenas, C.G.; Tsiplakides, D.; Balomenou, S.; et al. Ionically conducting ceramics as active catalyst supports. Chem. Rev. 2013, 113, 8192-8260. [CrossRef]

17. González-Cobos, J.; Valverde, J.L.; de Lucas-Consuegra, A. Electrochemical vs. chemical promotion in the $\mathrm{H}_{2}$ production catalytic reactions. Int. J. Hydrogen Energy 2017, 42, 13712-13723. [CrossRef]

18. Anastasijevic, N.A. NEMCA-From discovery to technology. Catal. Today 2009, 146, 308-311. [CrossRef]

19. Tsiplakides, D.; Balomenou, S. Milestones and perspectives in electrochemically promoted catalysis. Catal. Today 2009, 146, 312-318. [CrossRef]

20. Tsiplakides, D.; Balomenou, S. Electrochemical promoted catalysis: Towards practical utilization. Chem. Ind. Chem. Eng. Q. 2008, 14, 97-105. [CrossRef]

21. Marwood, M.; Vayenas, C.G. Electrochemical Promotion of a Dispersed Platinum Catalyst. J. Catal. 1998, 178, 429-440. [CrossRef]

22. De Lucas-Consuegra, A.; Princivalle, A.; Caravaca, A.; Dorado, F.; Marouf, A.; Guizard, C.; Valverde, J.L.; Vernoux, P. Preparation and characterization of a low particle size $\mathrm{Pt} / \mathrm{C}$ catalyst electrode for the simultaneous electrochemical promotion of $\mathrm{CO}$ and $\mathrm{C}_{3} \mathrm{H}_{6}$ oxidation. Appl. Catal. A Gen. 2009, 365. [CrossRef]

23. Jiménez, V.; Jiménez-Borja, C.; Sánchez, P.; Romero, A.; Papaioannou, E.I.; Theleritis, D.; Souentie, S.; Brosda, S.; Valverde, J.L. Electrochemical promotion of the $\mathrm{CO}_{2}$ hydrogenation reaction on composite $\mathrm{Ni}$ or Ru impregnated carbon nanofiber catalyst-electrodes deposited on YSZ. Appl. Catal. B Environ. 2011, 107, 210-220. [CrossRef]

24. De Lucas-Consuegra, A.; González-Cobos, J.; Carcelén, V.; Magén, C.; Endrino, J.L.; Valverde, J.L. Electrochemical promotion of Pt nanoparticles dispersed on a diamond-like carbon matrix: A novel electrocatalytic system for $\mathrm{H} 2$ production. J. Catal. 2013, 307, 18-26. [CrossRef]

25. González-Cobos, J.; Ruiz-López, E.; Valverde, J.L.; de Lucas-Consuegra, A. Electrochemical promotion of a dispersed Ni catalyst for $\mathrm{H} 2$ production via partial oxidation of methanol. Int. J. Hydrogen Energy 2016, 41, 19418-19429. [CrossRef]

26. Kambolis, A.; Lizarraga, L.; Tsampas, M.N.; Burel, L.; Rieu, M.; Viricelle, J.-P.; Vernoux, P. Electrochemical promotion of catalysis with highly dispersed Pt nanoparticles. Electrochem. Commun. 2012, 19, 5-8. [CrossRef]

27. Hajar, Y.; Di Palma, V.; Kyriakou, V.; Verheijen, M.A.; Baranova, E.A.; Vernoux, P.; Kessels, W.M.M.; Creatore, M.; van de Sanden, M.C.M.; Tsampas, M.N. Atomic layer deposition of highly dispersed Pt nanoparticles on a high surface area electrode backbone for electrochemical promotion of catalysis. Electrochem. Commun. 2017, 84, 40-44. [CrossRef]

28. Dole, H.A.E.; Safady, L.F.; Ntais, S.; Couillard, M.; Baranova, E.A. Electrochemically enhanced metal-support interaction of highly dispersed $\mathrm{Ru}$ nanoparticles with a $\mathrm{CeO}_{2}$ support. J. Catal. 2014, 318, 85-94. [CrossRef]

29. Zagoraios, D.; Athanasiadi, A.; Kalaitzidou, I.; Ntais, S.; Katsaounis, A.; Caravaca, A.; Vernoux, P.; Vayenas, C.G. Electrochemical promotion of methane oxidation over nanodispersed $\mathrm{Pd} / \mathrm{CO}_{3} \mathrm{O}_{4}$ catalysts. Catal. Today 2019. [CrossRef]

30. González-Cobos, J.; Rico, V.J.; González-Elipe, A.R.; Valverde, J.L.; De Lucas-Consuegra, A. Electrochemical activation of an oblique angle deposited $\mathrm{Cu}$ catalyst film for $\mathrm{H}_{2}$ production. Catal. Sci. Technol. 2015, 5, 2203-2214. [CrossRef]

31. González-Cobos, J.; Rico, V.J.; González-Elipe, A.R.; Valverde, J.L.; de Lucas-Consuegra, A. Electrocatalytic System for the Simultaneous Hydrogen Production and Storage from Methanol. ACS Catal. 2016, 6, 1942-1951. [CrossRef]

32. Yiokari, C.G.; Pitselis, G.E.; Polydoros, D.G.; Katsaounis, A.D.; Vayenas, C.G. High-Pressure Electrochemical Promotion of Ammonia Synthesis over an Industrial Iron Catalyst. J. Phys. Chem. A 2000, 104, 10600-10602. [CrossRef]

33. Balomenou, S.; Tsiplakides, D.; Katsaounis, A.; Thiemann-Handler, S.; Cramer, B.; Foti, G.; Comninellis, C.; Vayenas, C.G. Novel monolithic electrochemically promoted catalytic reactor for environmentally important reactions. Appl. Catal. B Environ. 2004, 52, 181-196. [CrossRef]

34. Hammad, A.; Souentie, S.; Balomenou, S.; Tsiplakides, D.; Figueroa, J.C.; Cavalca, C.; Pereira, C.J.; Vayenas, C.G. Tailor-structured skeletal Pt catalysts employed in a monolithic electropromoted reactor. J. Appl. Electrochem. 2008, 38, 1171-1176. [CrossRef] 
35. Hammad, A.; Souentie, S.; Papaioannou, E.I.; Balomenou, S.; Tsiplakides, D.; Figueroa, J.C.; Cavalca, C.; Pereira, C.J. Electrochemical promotion of the $\mathrm{SO}_{2}$ oxidation over thin Pt films interfaced with YSZ in a monolithic electropromoted reactor. Appl. Catal. B Environ. 2011, 103, 336-342. [CrossRef]

36. Papaioannou, E.I.; Souentie, S.; Hammad, A.; Vayenas, C.G. Electrochemical promotion of the $\mathrm{CO}_{2}$ hydrogenation reaction using thin $\mathrm{Rh}, \mathrm{Pt}$ and $\mathrm{Cu}$ films in a monolithic reactor at atmospheric pressure. Catal. Today 2009, 146, 336-344. [CrossRef]

37. Balomenou, S.P.; Tsiplakides, D.; Vayenas, C.G.; Poulston, S.; Houel, V.; Collier, P.; Konstandopoulos, A.G.; Agrafiotis, C. Electrochemical promotion in a monolith electrochemical plate reactor applied to simulated and real automotive pollution control. Top. Catal. 2007, 44, 481-486. [CrossRef]

38. Souentie, S.; Hammad, A.; Brosda, S.; Foti, G.; Vayenas, C.G. Electrochemical promotion of NO reduction by $\mathrm{C}_{2} \mathrm{H}_{4}$ in $10 \% \mathrm{O}_{2}$ using a monolithic electropromoted reactor with $\mathrm{Rh} / \mathrm{YSZ} / \mathrm{Pt}$ elements. J. Appl. Electrochem. 2008, 38, 1159-1170. [CrossRef]

39. TechNavio. Global Ethylene Oxide and Ethylene Glycol Market 2016-2020; TechNavio: London, UK, 2016.

40. Rebsdat, S.; Mayer, D. Ethylene Oxide. In Ullmann's Encyclopedia of Industrial Chemistry; Wiley-VCH: Weinheim, Germany, 2001; Vol. Organic Chemicals.

41. Van Santen, R.A.; Kuipers, H.P.C.E. The Mechanism of Ethylene Epoxidation. In Advances in Catalysis; Eley, D.D., Pines, H., Weisz, P.B.B.T.-A., Eds.; Academic Press: Cambridge, MA, USA, 1987; Volume 35, pp. 265-321. ISBN 0360-0564.

42. Kenge, N.; Pitale, S.; Joshi, K. The nature of electrophilic oxygen: Insights from periodic density functional theory investigations. Surf. Sci. 2019, 679, 188-195. [CrossRef]

43. Christopher, P.; Linic, S. Engineering Selectivity in Heterogeneous Catalysis: Ag Nanowires as Selective Ethylene Epoxidation Catalysts. J. Am. Chem. Soc. 2008, 130, 11264-11265. [CrossRef]

44. Campbell, C.T.; Paffett, M.T. The role of chlorine promoters in catalytic ethylene epoxidation over the Ag(110) surface. Appl. Surf. Sci. 1984, 19, 28-42. [CrossRef]

45. Van Hoof, A.J.F.; Filot, I.A.W.; Friedrich, H.; Hensen, E.J.M. Reversible Restructuring of Silver Particles during Ethylene Epoxidation. ACS Catal. 2018, 8, 11794-11800. [CrossRef]

46. Rocha, T.C.R.; Hävecker, M.; Knop-Gericke, A.; Schlögl, R. Promoters in heterogeneous catalysis: The role of $\mathrm{Cl}$ on ethylene epoxidation over Ag. J. Catal. 2014, 312, 12-16. [CrossRef]

47. Özbek, M.O.; van Santen, R.A. The Mechanism of Ethylene Epoxidation Catalysis. Catal. Lett. 2013, 143, 131-141. [CrossRef]

48. Sass, J.B.; Castleman, B.; Wallinga, D. Vinyl chloride. A case study of data suppression and misrepresentation. Environ. Health Perspect. 2005, 113, 809-812. [CrossRef] [PubMed]

49. Boghosian, S.; Bebelis, S.; Vayenas, C.G.; Papatheodorou, G.N. In situ high temperature SERS study of Ag catalysts and electrodes during ethylene epoxidation. J. Catal. 1989, 117, 561-565. [CrossRef]

50. Kondarides, D.L.; Papatheodorou, G.N.; Vayenas, C.G.; Verykios, X.E. In situ high temperature SERS study of oxygen adsorbed on Ag. Support and electrochemical promotion effects. Berichte der Bunsengesellschaft/Physical Chem. Chem. Phys. 1993, 97, 709-720. [CrossRef]

51. Bebelis, S.; Vayenas, C.G. Non-faradaic electrochemical modification of catalytic activity 6 . Ethylene epoxidation on Ag deposited on stabilized ZrO2. J. Catal. 1992, 138, 588-610. [CrossRef]

52. Karavasilis, C.; Bebelis, S.; Vayenas, C.G. Selectivity maximization of ethylene epoxidation via NEMCA with zirconia and $\beta^{\prime \prime}-\mathrm{Al}_{2} \mathrm{O}_{3}$ solid electrolytes. Ionics (Kiel) 1995, 1, 85-91. [CrossRef]

53. Karavasilis, C.; Bebelis, S.; Vayenas, C.G. Non-Faradaic Electrochemical Modification of Catalytic Activity: X. Ethylene Epoxidation on Ag Deposited on Stabilized $\mathrm{ZrO}_{2}$ in the Presence of Chlorine Moderators. J. Catal. 1996, 160, 190-204. [CrossRef]

54. Dole, H.A.E.; Isaifan, R.J.; Sapountzi, F.M.; Lizarraga, L.; Aubert, D.; Princivalle, A.; Vernoux, P.; Baranova, E.A. Low Temperature Toluene Oxidation Over Pt Nanoparticles Supported on Yttria Stabilized-Zirconia. Catal. Lett. 2013, 143, 996-1002. [CrossRef]

55. Hajar, Y.M.; Houache, M.S.E.; Tariq, U.; Vernoux, P.; Baranova, E.A. Nanoscopic Ni Interfaced with Oxygen Conductive Supports: Link between Electrochemical and Catalytic Studies. ECS Trans. 2017, 77, 51-66. [CrossRef]

56. Tsampas, M.N.; Sapountzi, F.M.; Vernoux, P. Applications of yttria stabilized zirconia (YSZ) in catalysis. Catal. Sci. Technol. 2015, 5, 4884-4900. [CrossRef] 
57. Nicole, J.; Tsiplakides, D.; Pliangos, C.; Verykios, X.; Comninellis, C.; Vayenas, C. Electrochemical Promotion and Metal-Support Interactions. J. Catal. 2001, 204, 23-34. [CrossRef]

58. Wang, Z.; Huang, H.; Liu, H.; Zhou, X. Self-sustained electrochemical promotion catalysts for partial oxidation reforming of heavy hydrocarbons. Int. J. Hydrogen Energy 2012, 37, 17928-17935. [CrossRef]

59. Zhou, X.; Huang, H.; Liu, H. Study of partial oxidation reforming of methane to syngas over self-sustained electrochemical promotion catalyst. Int. J. Hydrogen Energy 2013, 38, 6391-6396. [CrossRef]

60. Huang, H.; Wang, Z.; Liu, H.; Sun, H.; Wei, Y.; Zhou, X. A kinetic model for analyzing partial oxidation reforming of heavy hydrocarbon over a novel self-sustained electrochemical promotion catalyst. Int. J. Hydrogen Energy 2012, 37, 15125-15134. [CrossRef]

61. Huang, H.; Wang, Z.; Zhou, X.; Liu, H.; Wei, Y.; Pramuanjaroenkij, A.; Bordas, A.; Page, M.; Cai, S.; Zhang, X. Development and Study of Self-Sustained Electrochemical Promotion Catalysts for Hydrocarbon Reforming. ECS Trans. 2013, 58, 243-254. [CrossRef]

62. Poulidi, D.; Thursfield, A.; Metcalfe, I.S. Electrochemical promotion of catalysis controlled by chemical potential difference across a mixed ionic-electronic conducting ceramic membrane - An example of wireless NEMCA. Top. Catal. 2007, 44, 435-449. [CrossRef]

63. Stavrakakis, E.; West, M.; Johnston, S.; McIllwaine, R.; Poulidi, D. Hydration, $\mathrm{CO}_{2}$ stability and wireless electrochemical promotion studies on yttria-doped $\mathrm{Ba}(\mathrm{Ce}, \mathrm{Zr}) \mathrm{O}_{3}$ perovskites. Ionics (Kiel) 2019, 25, 1243-1257. [CrossRef]

64. Poulidi, D.; Rivas, M.E.; Zydorczak, B.; Wu, Z.; Li, K.; Metcalfe, I.S. Electrochemical promotion of a Pt catalyst supported on La0.6Sr0.4Co0.2Fe0.8O3- $\delta$ hollow fibre membranes. In Proceedings of the Solid State Ionics; Elsevier: Amsterdam, The Netherlands, 2012; Volume 225, pp. 382-385. [CrossRef]

65. Miyoshi, N.; Matsumoto, S.; Katoh, K.; Tanaka, T.; Harada, J.; Takahashi, N.; Yokota, K.; Sugiura, M.; Kasahara, K. Development of new concept three-way catalyst for automotive lean-burn engines. SAE Tech. Pap. 1995. [CrossRef]

66. Matsumoto, S. DeNOx catalyst for automotive lean-burn engine. Catal. Today 1996, 29, 43-45. [CrossRef]

67. Takahashi, N.; Shinjoh, H.; Iijima, T.; Suzuki, T.; Yamazaki, K.; Yokota, K.; Suzuki, H.; Miyoshi, N.; Matsumoto, S.; Tanizawa, T.; et al. The new concept 3-way catalyst for automotive lean-burn engine: NOx storage and reduction catalyst. Catal. Today 1996, 27, 63-69. [CrossRef]

68. Epling, W.S.; Campbell, L.E.; Yezerets, A.; Currier, N.W.; Parks II, J.E. Overview of the fundamental reactions and degradation mechanisms of NOx storage/reduction catalysts. Catal. Rev. Sci. Eng. 2004, 46, 163-245. [CrossRef]

69. Liu, G.; Gao, P.-X. A review of NOx storage/reduction catalysts: Mechanism, materials and degradation studies. Catal. Sci. Technol. 2011, 1, 552-568. [CrossRef]

70. Kim, D.H. Sulfation and Desulfation Mechanisms on Pt-BaO/ $\mathrm{Al}_{2} \mathrm{O}_{3}$ NOx Storage-Reduction (NSR) Catalysts. Catal. Surv. Asia 2014, 18, 13-23. [CrossRef]

71. Pancharatnam, S. Catalytic Decomposition of Nitric Oxide on Zirconia by Electrolytic Removal of Oxygen. J. Electrochem. Soc. 1975, 122, 869. [CrossRef]

72. Bredikhin, S.; Maeda, K.; Awano, M. NO decomposition by an electrochemical cell with mixed oxide working electrode. Solid State Ionics 2001, 144, 1-9. [CrossRef]

73. Awano, M.; Bredikhin, S.; Aronin, A.; Abrosimova, G.; Katayama, S.; Hiramatsu, T. NOx decomposition by electrochemical reactor with electrochemically assembled multilayer electrode. Solid State Ionics 2004, 175, 605-608. [CrossRef]

74. Hamamoto, K.; Fujishiro, Y.; Awano, M. Low-Temperature NOx Decomposition Using an Electrochemical Reactor. J. Electrochem. Soc. 2008, 155, E109. [CrossRef]

75. Hadjar, A.; Hernández, W.Y.; Princivalle, A.; Tardivat, C.; Guizard, C.; Vernoux, P. Electrochemical activation of Pt-Ba/YSZ NOxTRAP catalyst under lean-burn conditions. Electrochem. Commun. 2011, 13, 924-927. [CrossRef]

76. Wang, X.; Westermann, A.; Shi, Y.X.; Cai, N.S.; Rieu, M.; Viricelle, J.-P.; Vernoux, P. Electrochemical removal of NOx on ceria-based catalyst-electrodes. Catalysts 2017, 7. [CrossRef]

77. Tsampas, M.N.; Vernoux, P. Electrochemical Promotion of Catalysis for Automotive Post-Treatment and Air Cleaning. In New and Future Developments in Catalysis; Ch. 11; Elsevier Inc.: Amsterdam, The Netherlands, 2013; ISBN 9780444538703. 
78. Tang, X.; Xu, X.; Yi, H.; Chen, C.; Wang, C. Recent Developments of Electrochemical Promotion of Catalysis in the Techniques of DeNOx. Sci. World J. 2013, 2013, 463160. [CrossRef]

79. Williams, F.J.; Palermo, A.; Tikhov, M.S.; Lambert, R.M. First Demonstration of in Situ Electrochemical Control of a Base Metal Catalyst: Spectroscopic and Kinetic Study of the CO + NO Reaction over Na-Promoted Cu. J. Phys. Chem. B 1999, 103, 9960-9966. [CrossRef]

80. Williams, F.J.; Tikhov, M.S.; Palermo, A.; Macleod, N.; Lambert, R.M. Electrochemical promotion of rhodium-catalyzed NO reduction by CO and by propene in the presence of oxygen. J. Phys. Chem. B 2001, 105, 2800-2808. [CrossRef]

81. Williams, F.J.; Palermo, A.; Tikhov, M.S.; Lambert, R.M. Mechanism of alkali promotion in heterogeneous catalysis under realistic conditions: Application of electron spectroscopy and electrochemical promotion to the reduction of NO by CO and by propene over rhodium. Surf. Sci. 2001, 482-485, 177-182. [CrossRef]

82. Williams, F.J.; Palermo, A.; Tikhov, M.S.; Lambert, R.M. Electrochemical promotion by sodium of the rhodium-catalyzed NO + CO reaction. J. Phys. Chem. B 2000, 104, 11883-11890. [CrossRef]

83. Lambert, R.M.; Tikhov, M.; Palermo, A.; Yentekakis, I.V.; Vayenas, C.G. Electrochemical promotion of environmentally important catalytic reactions. Ionics (Kiel) 1995, 1, 366-376. [CrossRef]

84. Yentekakis, I.V.; Palermo, A.; Filkin, N.C.; Tikhov, M.S.; Lambert, R.M. In situ electrochemical promotion by sodium of the platinum-catalyzed reduction of NO by propene. J. Phys. Chem. B 1997, 101, 3759-3768. [CrossRef]

85. Williams, F.J.; Palermo, A.; Tikhov, M.S.; Lambert, R.M. Electrochemical promotion by sodium of the rhodium-catalyzed reduction of NO by propene: Kinetics and spectroscopy. J. Phys. Chem. B 2001, 105, 1381-1388. [CrossRef]

86. De Lucas-Consuegra, A.; Caravaca, Á.; Sánchez, P.; Dorado, F.; Valverde, J.L. A new improvement of catalysis by solid-state electrochemistry: An electrochemically assisted NOx storage/reduction catalyst. J. Catal. 2008, 259, 54-65. [CrossRef]

87. De Lucas-Consuegra, A.; Caravaca, A.; Martín de Vidales, M.J.; Dorado, F.; Balomenou, S.; Tsiplakides, D.; Vernoux, P.; Valverde, J.L. An electrochemically assisted NOx storage/reduction catalyst operating under fixed lean burn conditions. Catal. Commun. 2009, 11, 247-251. [CrossRef]

88. Christensen, H.; Dinesen, J.; Engell, H.H.; Hansen, K.K. Electrochemical reactor for exhaust gas purification. SAE Tech. Pap. 1999. [CrossRef]

89. Christensen, H.; Dinesen, J.; Engell, H.H.; Larsen, L.C.; Hansen, K.K.; Skou, E.M. Electrochemical exhaust gas purification. SAE Tech. Pap. 2000. [CrossRef]

90. Jena, P. Materials for hydrogen storage: Past, present, and future. J. Phys. Chem. Lett. 2011, 2, $206-211$. [CrossRef]

91. Klingmann, J.; Andersson, M. Hydrogen and Hydrogen-Rich Fuels: Production and Conversion to Electricity. In Innovations in Sustainable Energy and Cleaner Environment; Ch. 10; Gupta, A.K., De, A., Aggarwal, S.K., Kushari, A., Runchal, A., Eds.; Springer: Singapore, 2020; pp. 219-233. ISBN 978-981-13-9012-8.

92. Dodds, P.E.; Staffell, I.; Hawkes, A.D.; Li, F.; Grünewald, P.; McDowall, W.; Ekins, P. Hydrogen and fuel cell technologies for heating: A review. Int. J. Hydrogen Energy 2015, 40, 2065-2083. [CrossRef]

93. Apostolou, D.; Xydis, G. A literature review on hydrogen refuelling stations and infrastructure. Current status and future prospects. Renew. Sustain. Energy Rev. 2019, 113, 109292. [CrossRef]

94. Cipriani, G.; Di Dio, V.; Genduso, F.; La Cascia, D.; Liga, R.; Miceli, R.; Ricco Galluzzo, G. Perspective on hydrogen energy carrier and its automotive applications. Int. J. Hydrogen Energy 2014, 39, 8482-8494. [CrossRef]

95. Sengodan, S.; Lan, R.; Humphreys, J.; Du, D.; Xu, W.; Wang, H.; Tao, S. Advances in reforming and partial oxidation of hydrocarbons for hydrogen production and fuel cell applications. Renew. Sustain. Energy Rev. 2018, 82, 761-780. [CrossRef]

96. Busca, G.; Costantino, U.; Montanari, T.; Ramis, G.; Resini, C.; Sisani, M. Nickel versus cobalt catalysts for hydrogen production by ethanol steam reforming: $\mathrm{Ni}-\mathrm{Co}-\mathrm{Zn}-\mathrm{Al}$ catalysts from hydrotalcite-like precursors. Int. J. Hydrogen Energy 2010, 35, 5356-5366. [CrossRef] 
97. Megía, P.J.; Calles, J.A.; Carrero, A.; Vizcaíno, A.J. Effect of the incorporation of reducibility promoters $(\mathrm{Cu}, \mathrm{Ce}, \mathrm{Ag})$ in $\mathrm{Co} / \mathrm{CaSBA}-15$ catalysts for acetic acid steam reforming. Int. J. Energy Res. 2020, 1, 1-18. [CrossRef]

98. Chen, S.; Zaffran, J.; Yang, B. Dry reforming of methane over the cobalt catalyst: Theoretical insights into the reaction kinetics and mechanism for catalyst deactivation. Appl. Catal. B Environ. 2020, 270, 118859-118868. [CrossRef]

99. Budiman, A.W.; Song, S.-H.; Chang, T.-S.; Shin, C.-H.; Choi, M.-J. Dry Reforming of Methane Over Cobalt Catalysts: A Literature Review of Catalyst Development. Catal. Surv. Asia 2012, 16, 183-197. [CrossRef]

100. Osman, A.I. Catalytic hydrogen production from methane partial oxidation: Mechanism and kinetic study. Chem. Eng. Technol. 2020, 43, 641-648. [CrossRef]

101. Hossain, M.Z.; Charpentier, P.A. Hydrogen production by gasification of biomass and opportunity fuels. In Compendium of Hydrogen Energy; Ch. 6; Subramani, V., Basile, A., Veziroglu, T.N., Eds.; Woodhead Publishing: Sawston, UK, 2015; pp. 137-175.

102. Summa, P.; Samojeden, B.; Motak, M. Dry and steam reforming of methane. Comparison and analysis of recently investigated catalytic materials. A short review. Polish J. Chem. Technol. 2019, 21, 31-37. [CrossRef]

103. De Souza, V.P.; Costa, D.; dos Santos, D.; Sato, A.G.; Bueno, J.M.C. Pt-promoted $\alpha-\mathrm{Al}_{2} \mathrm{O}_{3}$-supported Ni catalysts: Effect of preparation conditions on oxi-reduction and catalytic properties for hydrogen production by steam reforming of methane. Int. J. Hydrogen Energy 2012, 37, 9985-9993. [CrossRef]

104. Borowiecki, T.; Denis, A.; Rawski, M.; Gołębiowski, A.; Stołecki, K.; Dmytrzyk, J.; Kotarba, A. Studies of potassium-promoted nickel catalysts for methane steam reforming: Effect of surface potassium location. Appl. Surf. Sci. 2014, 300, 191-200. [CrossRef]

105. Borowiecki, T.; Gołębiowski, A.; Ryczkowski, J.; Stasmska, B. The influence of promoters on the coking rate of nickel catalysts in the steam reforming of hydrocarbons. Stud. Surf. Sci. Catal. 1998, 119, 711-716. [CrossRef]

106. Alstrup, I.; Clausen, B.S.; Olsen, C.; Smits, R.H.H.; Rostrup-Nielsen, J.R. Promotion of Steam Reforming Catalysts. Stud. Surf. Sci. Catal. 1998, 119, 5-14. [CrossRef]

107. De Lucas-Consuegra, A.; Caravaca, A.; Martínez, P.J.; Endrino, J.L.; Dorado, F.; Valverde, J.L. Development of a new electrochemical catalyst with an electrochemically assisted regeneration ability for $\mathrm{H}_{2}$ production at low temperatures. J. Catal. 2010, 274, 251-258. [CrossRef]

108. Nurunnabi, M.; Mukainakano, Y.; Kado, S.; Miyazawa, T.; Okumura, K.; Miyao, T.; Naito, S.; Suzuki, K.; Fujimoto, K.-I.; Kunimori, K.; et al. Oxidative steam reforming of methane under atmospheric and pressurized conditions over Pd/NiO-MgO solid solution catalysts. Appl. Catal. A Gen. 2006, 308, 1-12. [CrossRef]

109. González-Cobos, J.; López-Pedrajas, D.; Ruiz-López, E.; Valverde, J.L.; de Lucas-Consuegra, A. Applications of the Electrochemical Promotion of Catalysis in Methanol Conversion Processes. Top. Catal. 2015, 58, 1290-1302. [CrossRef]

110. Deng, W.-Q.; Xu, X.; Goddard, W.A. New Alkali Doped Pillared Carbon Materials Designed to Achieve Practical Reversible Hydrogen Storage for Transportation. Phys. Rev. Lett. 2004, 92, 166103. [CrossRef]

111. Espinós, J.P.; Rico, V.J.; González-Cobos, J.; Sánchez-Valencia, J.R.; Pérez-Dieste, V.; Escudero, C.; de Lucas-Consuegra, A.; González-Elipe, A.R. In situ monitoring of the phenomenon of electrochemical promotion of catalysis. J. Catal. 2018, 358, 27-34. [CrossRef]

112. Espinós, J.P.; Rico, V.J.; González-Cobos, J.; Sánchez-Valencia, J.R.; Pérez-Dieste, V.; Escudero, C.; De Lucas-Consuegra, A.; González-Elipe, A.R. Graphene Formation Mechanism by the Electrochemical Promotion of a Ni Catalyst. ACS Catal. 2019, 11447-11454. [CrossRef]

113. Van Den Berg, A.W.C.; Areán, C.O. Materials for hydrogen storage: Current research trends and perspectives. Chem. Commun. 2008, 668-681. [CrossRef] [PubMed]

114. Dalebrook, A.F.; Gan, W.; Grasemann, M.; Moret, S.; Laurenczy, G. Hydrogen storage: Beyond conventional methods. Chem. Commun. 2013, 49, 8735-8751. [CrossRef]

115. Sapountzi, F.M.; Gracia, J.M.; Weststrate, C.J.K.-J.; Fredriksson, H.O.A.; Niemantsverdriet, J.W.H. Electrocatalysts for the generation of hydrogen, oxygen and synthesis gas. Prog. Energy Combust. Sci. 2017, 58, 1-35. [CrossRef]

116. Shiva Kumar, S.; Himabindu, V. Hydrogen production by PEM water electrolysis-A review. Mater. Sci. Energy Technol. 2019, 2, 442-454. [CrossRef] 
117. Ni, M.; Leung, M.K.H.; Leung, D.Y.C. Technological development of hydrogen production by solid oxide electrolyzer cell (SOEC). Int. J. Hydrogen Energy 2008, 33, 2337-2354. [CrossRef]

118. Lei, L.; Zhang, J.; Yuan, Z.; Liu, J.; Ni, M.; Chen, F. Progress Report on Proton Conducting Solid Oxide Electrolysis Cells. Adv. Funct. Mater. 2019. [CrossRef]

119. Sasikumar, G.; Muthumeenal, A.; Pethaiah, S.S.; Nachiappan, N.; Balaji, R. Aqueous methanol eletrolysis using proton conducting membrane for hydrogen production. Int. J. Hydrogen Energy 2008, 33, 5905-5910. [CrossRef]

120. Caravaca, A.; Sapountzi, F.M.; De Lucas-Consuegra, A.; Molina-Mora, C.; Dorado, F.; Valverde, J.L. Electrochemical reforming of ethanol-water solutions for pure $\mathrm{H}_{2}$ production in a PEM electrolysis cell. Int. J. Hydrogen Energy 2012, 37, 9504-9513. [CrossRef]

121. Caravaca, A.; De Lucas-Consuegra, A.; Calcerrada, A.B.; Lobato, J.; Valverde, J.L.; Dorado, F. From biomass to pure hydrogen: Electrochemical reforming of bio-ethanol in a PEM electrolyser. Appl. Catal. B Environ. 2013, 134-135. [CrossRef]

122. Calcerrada, A.B.; de la Osa, A.R.; Llanos, J.; Dorado, F.; de Lucas-Consuegra, A. Hydrogen from electrochemical reforming of ethanol assisted by sulfuric acid addition. Appl. Catal. B Environ. 2018, 231, 310-316. [CrossRef]

123. Calcerrada, A.B.; de la Osa, A.R.; Lopez-Fernandez, E.; Dorado, F.; de Lucas-Consuegra, A. Influence of the carbon support on the $\mathrm{Pt}-\mathrm{Sn}$ anodic catalyst for the electrochemical reforming of ethanol. Int. J. Hydrogen Energy 2019, 44, 10616-10626. [CrossRef]

124. Calcerrada, A.B.; de la Osa, A.R.; Dole, H.A.E.; Dorado, F.; Baranova, E.A.; de Lucas-Consuegra, A. Stability Testing of $\mathrm{Pt}_{\mathrm{x}} \mathrm{Sn}_{1-\mathrm{x}} / \mathrm{C}$ Anodic Catalyst for Renewable Hydrogen Production Via Electrochemical Reforming of Ethanol. Electrocatalysis 2018, 9, 293-301. [CrossRef]

125. Gutiérrez-Guerra, N.; Jiménez-Vázquez, M.; Serrano-Ruiz, J.C.; Valverde, J.L.; de Lucas-Consuegra, A. Electrochemical reforming vs. catalytic reforming of ethanol: A process energy analysis for hydrogen production. Chem. Eng. Process. Process Intensif. 2015, 95, 9-16. [CrossRef]

126. Ruiz-López, E.; Amores, E.; Raquel de la Osa, A.; Dorado, F.; de Lucas-Consuegra, A. Electrochemical reforming of ethanol in a membrane-less reactor configuration. Chem. Eng. J. 2020. [CrossRef]

127. De Lucas-Consuegra, A.; De La Osa, A.R.; Calcerrada, A.B.; Linares, J.J.; Horwat, D. A novel sputtered Pd mesh architecture as an advanced electrocatalyst for highly efficient hydrogen production. J. Power Sources 2016, 321, 248-256. [CrossRef]

128. Simões, M.; Baranton, S.; Coutanceau, C. Electrochemical valorisation of glycerol. ChemSusChem 2012, 5, 2106-2124. [CrossRef]

129. Coutanceau, C.; Baranton, S.; Kouamé, R.S.B. Selective electrooxidation of glycerol into value-added chemicals: A short overview. Front. Chem. 2019, 7. [CrossRef]

130. Haisch, T.; Kubannek, F.; Baranton, S.; Coutanceau, C.; Krewer, U. The influence of adsorbed substances on alkaline methanol electro-oxidation. Electrochim. Acta 2019, 295, 278-285. [CrossRef]

131. Coutanceau, C.; Baranton, S. Electrochemical conversion of alcohols for hydrogen production: A short overview. Wiley Interdiscip. Rev. Energy Environ. 2016, 5, 388-400. [CrossRef]

132. Ebbesen, S.D.; Jensen, S.H.; Hauch, A.; Mogensen, M.B. High Temperature Electrolysis in Alkaline Cells, Solid Proton Conducting Cells, and Solid Oxide Cells. Chem. Rev. 2014, 114, 10697-10734. [CrossRef]

133. Caravaca, A.; De Lucas-Consuegra, A.; Molina-Mora, C.; Valverde, J.L.; Dorado, F. Enhanced H2 formation by electrochemical promotion in a single chamber steam electrolysis cell. Appl. Catal. B Environ. 2011, 106. [CrossRef]

134. Ruiz-López, E.; Caravaca, A.; Vernoux, P.; Dorado, F.; de Lucas-Consuegra, A. Over-faradaic hydrogen production in methanol electrolysis cells. Chem. Eng. J. 2020, 396, 125217. [CrossRef]

135. Garcia-Garcia, F.J.; Yubero, F.; Espinós, J.P.; González-Elipe, A.R.; Lambert, R.M. Synthesis, characterization and performance of robust poison-resistant ultrathin film yttria stabilized zirconia - Nickel anodes for application in solid electrolyte fuel cells. J. Power Sources 2016, 324, 679-686. [CrossRef] 
136. Garcia-Garcia, F.J.; Beltrán, A.M.; Yubero, F.; González-Elipe, A.R.; Lambert, R.M. High performance novel gadolinium doped ceria/yttria stabilized zirconia/nickel layered and hybrid thin film anodes for application in solid oxide fuel cells. J. Power Sources 2017, 363, 251-259. [CrossRef]

137. Garcia-Garcia, F.J.; Yubero, F.; González-Elipe, A.R.; Balomenou, S.P.; Tsiplakides, D.; Petrakopoulou, I.; Lambert, R.M. Porous, robust highly conducting Ni-YSZ thin film anodes prepared by magnetron sputtering at oblique angles for application as anodes and buffer layers in solid oxide fuel cells. Int. J. Hydrogen Energy 2015, 40, 7382-7387. [CrossRef]

Publisher's Note: MDPI stays neutral with regard to jurisdictional claims in published maps and institutional affiliations.

(C) 2020 by the authors. Licensee MDPI, Basel, Switzerland. This article is an open access article distributed under the terms and conditions of the Creative Commons Attribution (CC BY) license (http://creativecommons.org/licenses/by/4.0/). 